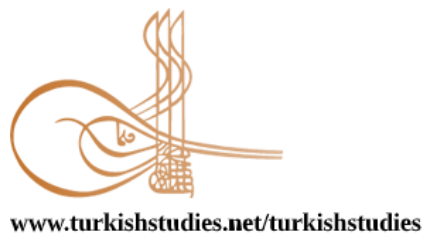

Turkish Studies

www.turkishstudies.net/turkishstudies

eISSN: $1308-2140$

BALKAN
UNIVERSITY

Sponsored by IBU

Research Article / Araştırma Makalesi

\title{
Covid-19 Sonrası Türk Sinema Endüstrisi Üzerine Bir İnceleme
}

A Study on Turkish Cinema Industry After Covid-19

\author{
Mesut Aytekin*
}

\begin{abstract}
Cinema is one of the most important mass media in the 20th century with its artistic and commercial aspects. Cinema, which is the fastest carrier of the mass industry with the words of Adorno, has experienced many crises since its first show in Paris in 1895. Wars, diseases, economic and political debates, social events have affected the structure of the cinema. Despite all the negativities, cinema continued its development, albeit within limited possibilities. However, the Covid-19 virus, which has influenced the world, has brought all industries to a halt with the announcement of the World Health Organization as a pandemic. One of the industries most affected by this process was the cinema industry. The countries entering the quarantine process and imposing restrictions, prohibitions on social life have also disrupted the production (production) and distribution / screening stages of the cinema industry. The projects being taken were interrupted, those in the shooting phase were stopped, movie theaters were closed, screenings were canceled or postponed. The crisis that took place in an active period of the sector affected both cinema workers, production companies, distribution companies and audiences. The simultaneous influence of the Covid-19 crisis all over the world prevented the cinema industries from receiving support from other country cinema industries.

The Turkish Cinema industry, which started to rise after 2005, was deeply shaken by the Covid-19 crisis it faced with its structural problems. In this study, after Covid-19, documentary sources are scanned across the world and Turkish cinema industries, and developments in Turkish Cinema are analyzed with the descriptive analysis method within the context of cinema value chain. The crisis caused by Covid-19 in cinema is discussed with the developments, problems and solutions in Turkish Cinema.
\end{abstract}

Structured Abstract: Cinema is one of the most important mass media in the 20th century with its artistic and commercial aspects. Cinema, which is the fastest carrier of the mass industry with the words of Adorno, has experienced many crises since its first show in Paris in 1895. Wars, diseases, economic and political debates, social events have affected the structure of the cinema. Despite all the negativities, cinema continued its development, albeit within limited possibilities. However, the Covid-19 virus, which has influenced the world, has brought all industries to a halt with the announcement of the World Health Organization as a pandemic. One of the industries most affected by this process was the cinema industry. The countries entering the quarantine process and imposing restrictions, prohibitions on social life have also disrupted the production (production) and distribution / screening stages of the cinema industry. The projects being taken were interrupted, those in the shooting phase were stopped, movie theaters were closed, screenings were canceled or postponed. The crisis that took place in an active period of the sector affected both cinema workers, production companies, distribution companies and audiences. The simultaneous influence of the Covid-19

\footnotetext{
* Dr. Öğr. Üyesi, İstanbul Üniversitesi, İletişim Fakültesi, Radyo, TV ve Sinema Asst Prof. Dr, İstanbul University, Faculty of Communication, Radio, TV and Cinema ORCID: 0000-0003-0344-868X mesutaytekin@gmail.com

Cite as/ Atıf: Aytekin, M. (2020). Covid-19 sonrası Türk sinema endüstrisi üzerine bir inceleme. Turkish Studies, 15(4), 69-93. https://dx.doi.org/10.7827/TurkishStudies.44475

Received/Geliş: 23 June/Haziran 2020

Accepted/Kabul: 28 August/Ağustos 2020

Copyright (C) MDE, Turkey

Checked by plagiarism software

Published/Yayın: 30 August/Ağustos 2020

CC BY-NC 4.0
} 
crisis all over the world prevented the cinema industries from receiving support from other country cinema industries.

The Turkish Cinema industry, which started to rise after 2005, was deeply shaken by the Covid-19 crisis it faced with its structural problems. In this study, after Covid-19, documentary sources are scanned across the world and Turkish cinema industries, and developments in Turkish Cinema are analyzed with the descriptive analysis method within the context of cinema value chain. The crisis caused by Covid-19 in cinema is discussed with the developments, problems and solutions in Turkish Cinema.

Turkish Cinema, which had a troubled 2019 with the wars of popcorn, the change of the cinema law and digital platform discussions, was deeply shaken by the Covid-19 crisis. The cessation of all stages of the industry has caused great economic damage, thousands of people have been unemployed, cinemas have been closed, festivals, competitions, events have been canceled, postponed.

With the expanding time frame for the idea phase, the sector had the opportunity to evaluate its accumulated projects, to further improve and develop its existing projects, to produce new projects. A much more systematic working environment has been created for cast design. Cleaning and control of the technical devices were done carefully.

The delay of the production phase, which is one of the most problematic stages, will cause a chain hitch in the sector. The shooting of some films has also been postponed to the coming years, as the congestion to be experienced in the new season will prevent getting history due to the films that have been interrupted and postponed. The difficulty of shooting within the framework of the pandemic rules and the increase in costs discourage the production companies from going on the set.

With the increasing costs in the industry, the production companies will be directed to more plain film projects that can be shot more affordable and ready for vision instead of risky projects. This will prepare the ground for the shooting of films with dramatic structure, visual strength, cinematographic expression. This process, in which independent filmmakers are accustomed in many ways, creates a suitable environment for shooting minimal and successful films. It is possible to present different, innovative and original projects with a new language.

The biggest stage of the cinema industry was the distribution and screening stage. This large source of income, which provided cash flow to the industry, had to close during the busiest period of the industry. In this process, digital platforms, which have become popular in recent years, but not as much as the world cinema industry, have been introduced as a new screening medium. Collaboration with other Cinema and Blu TV, IKSV and MUBI, and the online screenings of the Istanbul Film Festival have been exemplary practices in this regard.

The Covid-19 crisis served as a catalyst in the digitization process, demonstrating that digitalization should be included in the cinema industry value chain. It became clear that new business models should be defined for the industry. Along with digital platforms, social media networks, websites, online platforms drew attention as different and alternative ways of meeting the industry with the target audience.

Movie theaters will open their doors to cinema lovers in a controlled manner in the new normalization process by organizing according to new rules and measures. However, the audience will go to the cinema very little due to the uncertainty caused by the uncertainty of the process and the epidemic. The audience can be persuaded to come to the cinema with regular shows, discount tickets and persuasive marketing methods, which are continued in a disciplined manner.

After the Covid-19 crisis, film production will further decrease in new shooting conditions. This will cause a decrease in the number of movies to be released. Movie theaters may extend the duration of the films in the vision to close the gap, or try to fill the gap with foreign films or reduce the number of halls and sessions.

Festivals were also a screening medium that suffered greatly from the crisis of Covid-19. The festivals that brought the Turkish cinema industry together and showcased new films and directors lost their influence in this period. However, they moved to the digital world with online projects and had a different experience.

The Turkish cinema industry will not be able to get rid of this crisis environment in a very short time, where it is shaken deeply along with the whole chain of values and directly and indirectly affects many sectors. Turkish Cinema will have to go through changes in its production style. Along with the financial loss, the worn 
out structure of the sector will lead the Turkish cinema industry to shrink. In order for the Covid-19 crisis to be overcome and the industry's structural problems to be solved, all stakeholders of the state and the private sector need to come together to produce solutions and create a road map within the framework of a common mind.

Keywords: Cinema, Covid-19, Turkish Cinema, Turkish Cinema Industry, World Cinema Industry, Production

Öz: Sinema hem sanatsal hem de ticari yönü ile 20. yüzyllın en önemli kitle iletişim araçlarından biridir. Adorno'un ifadesiyle kitle endüstrisinin en hızlı taşıyıcısı olan sinema, 1895 yılında Paris'te yapılan ilk gösteriminden bugüne pek çok kriz yaşamıştır. Savaşlar, hastalıklar, ekonomik ve siyasi tartışmalar, toplumsal olaylar sinemanın yapısını etkilemiştir. Tüm olumsuzluklara rağmen sinema sınırlı imkanlar dahilinde de olsa gelişimini sürdürmüştür. Ancak dünyayı etkisi altına alan Covid-19 virüsü, Dünya Sağlı Örgütü’nün pandemi ilan etmesi ile birlikte tüm endüstrileri durdurma noktasına getirmiştir. Bu süreçten en çok etkilenen endüstrilerden biri de sinema endüstrisi olmuştur. Ülkelerin karantina sürecine girmesi ve sosyal yaşama kısıtlamalar, yasaklar getirmesi, sinema endüstrisinin de özellikle yapım (üretim) ve dağıtım/gösterim aşamalarını sekteye uğratmıştır. Çekilmekte olan projelere ara verilmiş, çekim aşamasındakiler durdurulmuş, sinema salonları kapatılmış, gösterimler iptal edilmiş ya da ertelenmiştir. Sektörün aktif olduğu bir dönemde gerçekleşen kriz, hem sinema çalışanlarını hem yapım şirketlerini hem dağıtım şirketlerini hem de seyircileri etkilemiştir. Covid-19 krizinin bütün dünyayı eş zamanlı olarak etkisi altına alması, sinema endüstrilerinin diğer ülke sinema endüstrilerinden destek almasını da engellemiştir.

2005 sonrası yükselişe geçen Türk sinema endüstrisi yapısal sorunları ile birlikte karşılaştığı Covid-19 krizi ile derinden sarsılmıştır. Bu çalışmada, Covid-19 sonrası dünya ve Türk sinema endüstrileri genelinde belgesel kaynak taraması yapılarak Türk Sineması özelinde yaşanan gelişmeler, sinema değerler zinciri bağlamında betimsel analiz yöntemiyle incelenmektedir. Covid-19'un sinemada meydana getirdiği kriz, Türk Sineması'nda yaşanan gelişmeler, sorunlar ve çözüm yolları ile birlikte tartışılmaktadır.

Anahtar Kelimeler: Sinema, Covid-19, Türk Sineması, Türk sinema endüstrisi, Dünya Sinema Endüstrisi, Yapım.

\section{Giriş}

Fransız Lumiere Kardeşlerin 1895 yılında sinematograf adını verdikleri aygıt ile çektikleri ilk filmleri Paris'teki Grand de Cafe'de bir ücret karşıllı̆ında toplu olarak göstermeleri sinemanın başlangıcı olarak kabul edilmektedir. Sinema, sanatsal ve kültürel kaygılar ile birlikte maddi yönü de bulunan bir endüstridir. Endüstrinin işleyebilmesi için sermaye önemli bir unsurdur. İlk gösterim sonrası artan ilgi ve yeni gösterimler sinemanın maddi olarak bir getirisi olacağını göstermiştir. Bu durum yeni girişimcilerin ve sinemacıların ortaya çıkmasına zemin hazırlamıştır.

İnsanoğlunun yaşanmış öykülerini, edebiyatını, hayallerini, düşüncelerini farklı sanat dallarının gücü ile birleştirerek görsel bir şov içinde sunan sinema, tarihsel süreç içerisinde pek çok siyasi, ekonomik ve sosyal olaydan etkilenmiştir. Kitleleri etkileyen sinema bu gelişmeler ve gelişen teknoloji 1şı̆̆ında hem kendini keşfetmiş hem de zamanın şartları gereği şekillenmiştir. Örneğin I. Dünya Savaşı, 1918 İspanyol Gribi, II. Dünya Savaşı, soğuk savaş, televizyonun ortaya çıkışı, videonun gelişimi sinemayı derinden etkileyen olaylardır.

Çin'in Wuhan kentinde ortaya çıan Covid-19 virüsü de dünyayı sarsan önemli olaylardan biri olmuştur. Asya'dan başlayarak çok hızlı bir şekilde dünyayı etkisi altına alan Covid-19, uluslararası boyuta ulaşmış, Dünya Sağlik Örgütü pandemi ilan etmiştir. Ölümcül etkiye sahip pandemi karşısında sert önlemler alan ülkeler, sokağa çıma yasakları ilan etmiş, sosyal ve iş hayatını durdurmak zorunda kalmış, sınırları kapatmıştır. Karantina ile geçen mart ve nisan ayları sonunda mayıs ile normalleşme sürecine giren dünyada 6 milyon 430 binden fazla kişiyi salgından etkilenmişitr (The Wretched, 2020). 
Türkiye'de 11 Mart'ta görülen ilk vakanın ardından başlayan kısıtlamalar, 16 Mart tarihi itibariyle İçişleri Bakanlığı'nın 81 il valiliğine gönderdiği “corona virüs tedbirleri” konulu ek bir genelgeyle ciddi boyutlara ulaştı. Bu genelge ile sinemalar kapand1, vizyondaki filmlerin gösterimleri durdu, vizyon bekleyen filmler tarihlerini ertelemek zorunda kald1, galalar iptal edildi, festivaller ertelendi, setler paydos etti, çekimlere ara verildi. Türk sinema endüstrisi Covid-19 pandemisi ile büyük bir krize girdi. BKM CEO'su Zümrüt Arol Bekçe'nin de ifade ettiği gibi sinema endüstrisi bu derece büyük bir krizle global ölçekte ilk defa karşılaşmıştı ve buna hazırlıklı olması mümkün değildi (Box, 2020).

\section{Covid-19 ve Dünya Sineması}

İnsanoğlu ile yakından ilişkili bir endüstri olarak sinema uzun tarihi geçmişinde birçok sorun, kriz, tarihi, sosyal, siyasal ve ekonomik olay ile karşılaştı. Bu olaylar karşısında üretimler azalıp gösterimlere ara verilirken çeşitli çözüm yolları üretildi. Akademisyen Doç. Dr. Hakan Erkılıç Covid-19 krizinin belli yönleri ile sinema üzerinde 1918 İspanyol krizi sürecindeki gibi bir etki oluşturduğunu ifade etmektedir (Yılmaz, 2020):

"Pandemi ile birlikte Amerika Birleşik Devletleri'nde sinema salonları kapanır, yapımcılar film yapımını durdurur. Krizden en çok bağımsız sinema salonu işletmecileri ve küçük yapımcılar etkilenir. Kriz, neredeyse 70'li ylllara kadar devam eden ve literatüre 'Hollywood Stüdyo Sistemi' olarak geçen dikey bir örgütlenmeye sahip yapının doğmasına neden olur."

Ancak Covid-19 krizi hem ülke sinema endüstrilerini hem de dünya sinema endüstrisini aynı anda etkileyerek sistemin tamamının durmasına sebep olmuştur. Bu bütüncül etki, hazırlıksız yakalanma, belirsiz süreç, krizi daha da derinleştirmiş̧ir. Nisan ayı verilerine göre dünyanın en büyük 10 sinema pazarında yaşanan gişe kaybı yaklaşık yüzde 59'dur (Tezel, 2020). 35 bin salon, y1lda 15 milyar dolarlık sinema endüstrisi ile dünya sinema endüstrisinin neredeyse \%80'nini oluşturan Amerikan sinema endüstrisi, pandemiden en çok zarar gören sinema endüstrilerinin başında gelmektedir (Özgül, 2020). Moffett Nathanson'ın ABD gişelerine dair yayımladığı raporda ABD'de salonlar 1 Temmuz itibarıyla açılabilse bile yaklaşı 6 milyar dolarlık bir kayıp ortaya çıkacağı öngörülmektedir (Aydemir, 2020).

Dünyanın popüler dijital platformlarından biri olan Netflix, pek çok ülkede prodüksiyonlarını durdurduğu için platforma bağlı 120.000 sektör çalışanı işsiz kaldı (Kulaklı, 2020). Sinema endüstrisinin farklı alanlarında 227 bin kişi çalıştıran Disney, Avrupa ve Asya'daki parklarını da kapatınca 100 bin kişiyi işten çıkardı (Uluç A, 2020). Pek çok sinema işçisinin ücretsiz izne ayrıldığı ya da işsiz kaldığı Amerika'da büyük sinema zincirleri de büyük sıkıntıya girdi. Sinema salonlarının kapanmasıyla 150 bin kişi işsiz kaldı (Uluç 2, 2020). AMC Theatres, CEO'su da dahil olmak üzere 600 çalışanını ücretsiz izine çıkardı (ABD, 2020). Kuruluşu 1920'lere uzanan AMC Theatres'in Amerika'da 661 lokasyonda 8 bin 200 salonu, Avrupa'da ise 244 lokasyonda 2 bin 200 salonu bulunuyor (Aydemir, 2020). AMC Theatres'in durumu sinema salonlarının Covid-19 krizinden ne ölçüde etkilendiğinin anlaşılması açısından çarpıcı bir örnektir.

Dünyanın en büyük 10 sinema pazarından 5'inin yer aldığ Asya-Pasifik bölgesinde de büyük düşüş yaşanmaktadır. Bölge sinema endüstrilerinde 2020 yılının ilk çeyreğinde gişede $\% 88$ düşüş gözlendi (Asya'da, 2020). Bu oran ülkeler bazında ABD'den sonra dünyanın en güçlü sinema endüstrilerine sahip olan Çin'de \%39, Japonya'da \%46, Güney Kore'de ise \%65'tir (Uluç A, 2020).

Avrupa sinema endüstrisi de özellikle İngiltere, Almanya, Fransa sinema endüstrileri büyük kayıplar yaşadı. Örneğin İngiltere'de 2019 yılı verilerine göre film, TV ve radyo sektörlerinde çoğu serbest çalışan 240 bin kişi işsiz kaldı (Youngs, 2020). Almanya'da pek çok sinema salonu kapanma tehlikesi yaşarken mayıs ayında Alman Sinema Derneği, kısıtlamalar iki ay daha devam ederse sinema salonlarının yarısının iflas edebileceğini söyledi (Koronavirüsün, 2020). 
Devam eden pandemi sürecindeki belirsizlik sinema endüstrisinin normal işleyişe geçmesini engellemektedir. Yapılan analizlere göre dünya sinema endüstrisinin 2020 yılı zararı 20 milyar dolar civarında olacaktır (Box Office, 2020).

\section{Türk Sineması'na Genel Bir Bakış}

Ekonomik sosyal ve özellikle teknolojik gelişmeler, Türkiye'nin dünyaya açılması ve daha entegre politikaların izlenmesi, kitle iletişim araçlarının gelişerek daha etkin hale gelmesi sinemaya olan ilgiyi arttırdı. Yükselen seyirci sayısı ile birlikte ekonomik getirisinin artması sinemada üretimi teşvik etti, film festivalleri ve yarışmalar çoğaldı. Sinema eğitimi veren kurumlar çoğaldı. Türk filmleri yurtdışı festivallerden ödüllerle dönmeye başladı. Türk sinema endüstrisi yeniden yapılanarak dünya standartlarında ürünlere imza attı. Teknik alt yapı güçlendirildi. Türk sineması ticari filmler ve sanat filmleri şeklinde iki koldan gelişimini sürdürdü. Yeni sinema salonları ve perdeler açıldı. Mahalle sinemaları yerlerini AVM sinemalarına bıraktı. 2000 yılında 29 filmle çok az sayıda başlayan süreç gelişerek 2014 sonrası her yıl 100'ü aşkın yerli filmin çekilmesi ve vizyona girmesi ile birlikte Avrupa'nın en çok yerli film izleyen endüstrisine dönüştü. Yeni yapım şirketlerinin kurulmasıyla birlikte ilk filmlerini çeken yönetmen sayısı arttı. Tür ve konu çeşitliliği Türk Sineması'nı zenginleştirdi. Devletin sinemaya verdiği destek oranları çeşitlenerek pek çok belgesel, kısa, animasyon ve uzun metraj film projesinin hayata geçirilmesini sağladı.

Covid-19 öncesi 2019 yılında kamuoyuna "mısır savaşları" olarak geçen promosyon tartışmaları Türk sinema endüstrisini duraklama dönemine soktu. Promosyonlu bilet satışlarındaki anlaşmazlık sebebiyle Yılmaz Erdoğan, Cem Yılmaz, Şahan Gökbakar, Mahsun Kırmızıgül'ün büyük bütçeli filmlerini vizyona sokmaması ve ertelemesi, vizyon takvimini karıştırdı. Pek çok Türk filmi, vizyon takvimindeki belirsizlik yüzünden vizyon tarihlerini ertelemek zorunda kaldı. Yapım şirketleri, TC Kültür ve Turizm Bakanlığı ile görüşmelerde bulundular. Bakanlık sektörün beklentileri doğrultusunda 5224 sayılı kanunda özellikle promosyon, reklam ve sinema filmlerinin sınıflandırılması maddelerinde değişiklikler yaptı. Sinema salonlarını ve dizileri ve film tanıtım faaliyetlerini destekleme kararı alarak endüstriye yapılan yardımların alanını genişletti.

Bu süreçte Yılmaz Erdoğan vizyonda iken Organize İşler Sazan Sarmalı filmini Netflix’te yayımladı. Bu gösterim sinema salonlarının sert tepkisine neden oldu. Sektör paydaşları bu anlamda ikiye bölündü. Bir bölüm dijital platformların, sinemaların rakibi olarak konumlandırdı ve sinemaya zarar verdiğini dile getirdi; diğer bölümü ise dijital platformların da bir gösterim mecrası olduğunu yeni kaynaklar sağladığını ifade etti. Sorunlu bir sinema sezonu geçiren Türk Sineması 2019 yılında hasılat, seyirci ve sinema salonları bağlamında kayıplar yaşadı.

“Türkiye İstatistik Kurumu'nun (TÜIK) verilerine göre sinema seyirci sayısı 2019 yılında, 2018 yılına göre yüzde 12,8 azalarak 56 milyon 479 bin 209 kişi oldu. Yerli film seyirci sayısı yüzde 17,5 azalarak 32 milyon 331 bin 764 kişi olurken, yabanc1 film seyirci sayısı yüzde 5,6 azalarak 24 milyon 147 bin 445 kişi oldu." (Sinema, 2020) 


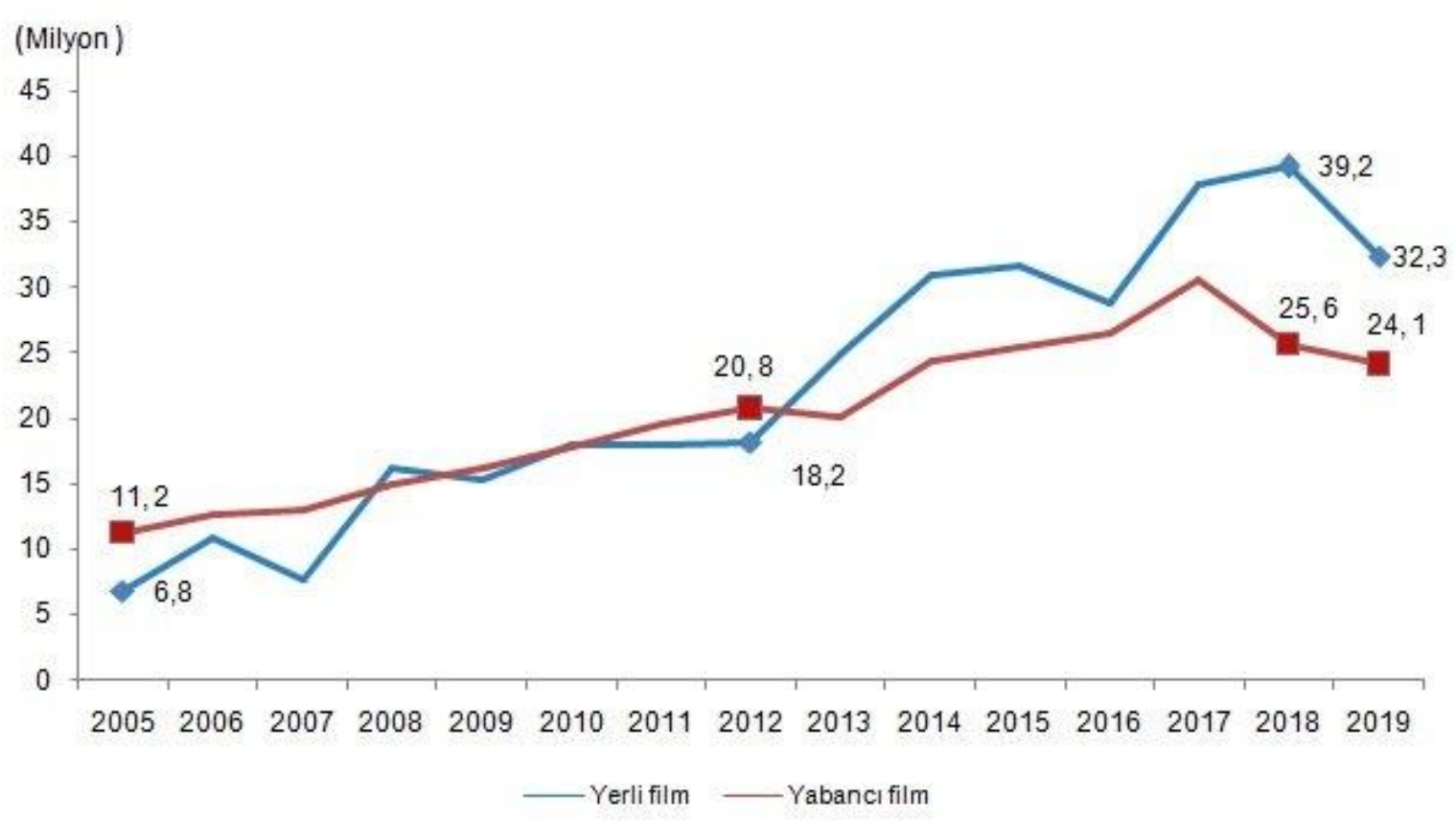

Grafik 1: Sinema Seyirci Sayıs1 2005-2019 (Sinema, 2020)

Türkiye genelinde sinema salonu sayıs1 2019 y1lında, 2018 yılına göre \%1,1 azalarak 2 bin 826, sinema salonlarındaki koltuk sayısı \%1,4 azalarak 337 bin 914 oldu. (Sinema ve, 2020)

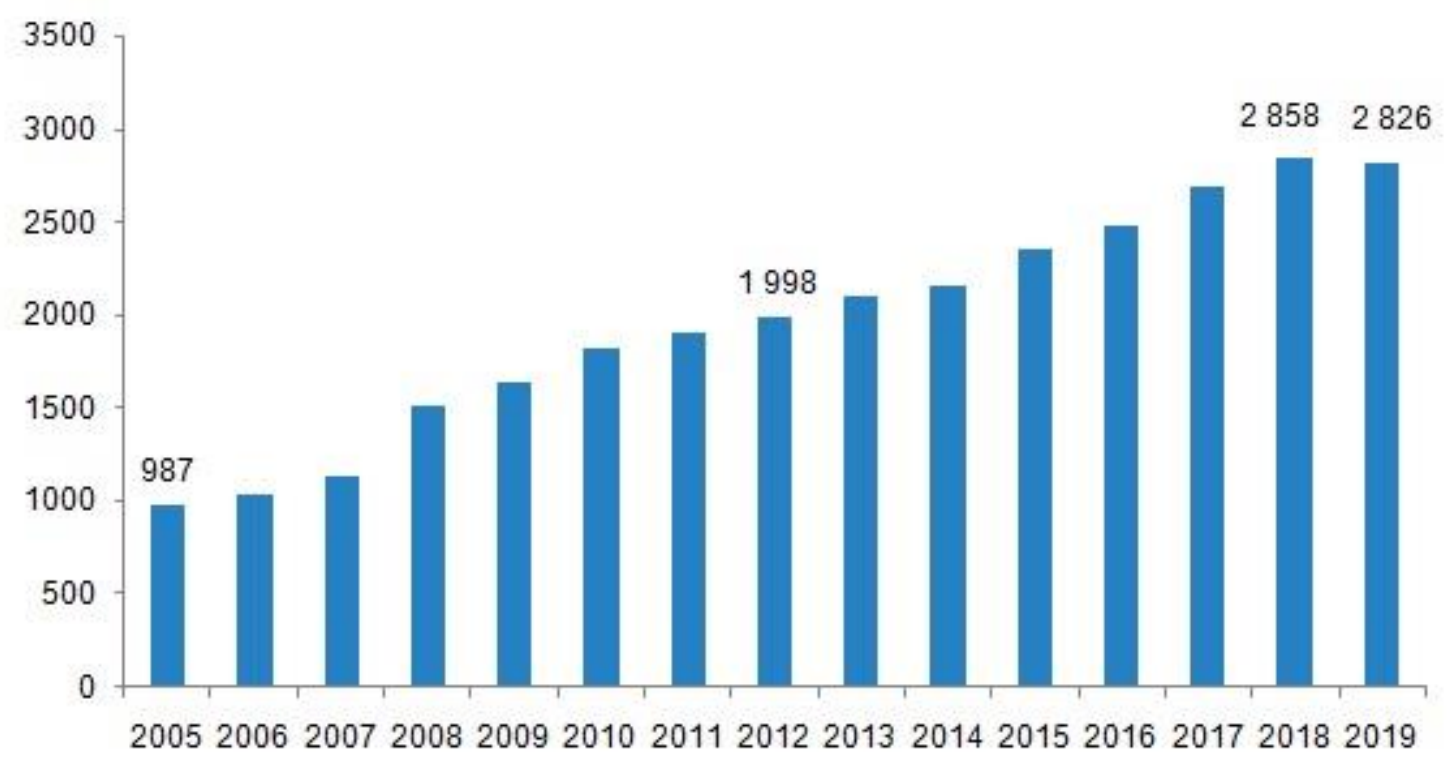

Grafik 2: 2005-2019 Sinema Salonu Sayısı (Sinema, 2020)

2019 yılında da Türk Sineması'nın parlak bir grafik çizmediğine vurgu yapan Ay Yapım İdari Yapımcılarından Yamaç Okur, Türk Sineması'nda 2019 yılında yaklaşık \%35'lik bir daralma 
yaşadığını ancak bilet fiyatlarındaki artışın daralmanın hasılata yansımasını engellediğini belirtiyor (Box, 2020).

\section{Covid-19 ve Türk Sineması}

Türk Sineması kendi içinde atlatamadığı krizlerin etkisi ile girdiği 2020 y1lında yeniden toparlanmayı beklerken Covid-19 krizi ile bir kez daha sarsıldı. Cinetech Sinemaları Genel Müdürü Murat Aslan, geçen yıl endüstriyi etkileyen tartışmanın etkisi üzerine Covid-19 krizinin yaşanmasının endüstride yeni bir "dip" yarattığını belirtti (Çalışkan, 2020). Sezonun en yoğun olduğu dönemlerde sinema salonlarının kapanması endüstrinin en önemli gelir kaynağını durdurdu. Dağıtımc1 ve yapımc1 CJ Entertainment Turkey'in Genel Müdür Yardımcısı Ferhat Aslan, nisan sonuna kadar Türk sinema endüstrisinin toplamda 150 milyon TL brüt gelir kaybı olduğunu söyledi (Çalışkan, 2020). Türk Sinema pazarının geçen yıl \%35.99'una sahip olan CJ Entertainment (120 lokasyonu, 2 bin personeli var), 2019'da 65 film dağıtımı gerçekleştirirken 2020'nin ilk çeyreğinde sadece 20 filmin dağıtımını yaptı.

Tablo 1: CJ Entertainment 2019-2020 Film Grafiği

\begin{tabular}{|l|l|l|}
\hline & $\begin{array}{l}\text { CJ Entertainment Turkey 2020 İlk Çeyrek } \\
\text { (Sinema Salonlarının Kapanmasına Kadar } \\
\text { Olan Süreç) }\end{array}$ & CJ Entertainment Turkey 2019 \\
\hline Dağıtım Yapılan Film Sayısı & 20 & 65 \\
\hline İzleyici Sayısı & 5.149 .214 Kişi & 21.433 .712 Kişi \\
\hline Pazar Payı & $\% 31.45$ & $\% 35.99$ \\
\hline Filmlerin Hasılatı & 87.547 .289 TL & 344.081 .783 TL \\
\hline Pazar Payı & $\% 31.20$ & $\% 35.10$ \\
\hline
\end{tabular}

MARS Entertainment Group'un otaklarından ve CEO'su Muzaffer Yıldırım, Türk Sinemas1 endüstrisini durumunun pek parlak olmadığını ifade etmektedir: " 2019 'da 60 milyon bilet sattık. Bu yıl karantina başlayana dek 16.5 milyon bilet oldu, sayı. Temmuzda sinemalar açılsa bile bu y1l toplam en fazla 25 milyon bilet satılır ancak. Yaz sezonu zaten sönüktür, her yerde. Eylülde yeni sezon aç1lır ama orda da durum parlak değil!” (Uluç, 2020)

Pandemi sebebiyle film çekimlerine de ara verilmesi, yeni projelerin ertelenmesi ile birlikte Türk sinema endüstrisi içerisindeki pek çok faaliyette sona erdi. Festivallerin bir bölümü iptal edildi, bir bölümü ertelendi bir bölümü ise online olarak etkinlik ve gösterimlerini gerçekleştirmeye çalıştı. Tamamı etkilenen endüstri doğrudan ve dolaylı etkileşimde bulunduğu sektörleri de etkilemiş, işsizlik oranlarında artış olmuştur.

Bu ölçekte bir kriz ile karşılaşmamış olan Türk sinema endüstrisi, pandeminin geçici olacağ 1 düşüncesi ile ilk günlerde pek tepki vermedi ve süreci takip etti. Ancak dünya sinema endüstrisine entegre yaşanan Covid-19 krizi gün geçtikçe endüstrideki sorunları büyüttü.

Bu sorunlar karşısında küçük sinema ve işletmelerin dayanmasının zor olduğunu ifade eden Yıldırım, büyük kapanmaların olacağını bu süreçte AVM'lerdeki zincirlerin bile yaşamasının zor olduğunu söylemektedir (Uluç, 2020).

Aslan'a göre eylül ayına kadar Türk Sineması'nın hasılat kaybı 300 milyon TL civarında olacaktır (Box Office, 2020). Aslan, bu koşullar altında 2020 yılında toplam seyircinin 40 milyona ulaşmasının bile büyük bir başarı olacağını öngörmektedir.

Insignia Yapım'ın Kurucu-Yönetici Ortağı Dorukhan Acar ise bütün faktörlerin normal çalıştı̆̆ durumda Türk sinema endüstrisinin pik yaptı̆̆ 
bilet satış rakamlarına ancak 2022'de ulaşabileceğini belirtmektedir: "Tek değişkenin pandemi olduğu bir senaryoda 2022 yılı sonunda 5 yıl öncesinin rakamlarını görmek mümkün olabilir. Ancak şahsi beklentim önümüzde 3 y1l, pandemi sonrası 'yeni normal'de 50-60 milyon biletlik bir pazarda yaşayacağımız." (Yılmaz 4, 2020)

Yıldırım, 30-35 milyon bilet sayısına ulaşılırsa Türk sinema endüstrisinin ayakta kalabileceğini yoksa sinema salonlarının yarısı kapanacağını ve sektörün kurtulmasının zor olduğunu ve bir çöküş yaşayacağını iade etmektedir (Karayel, 2020).

Sinema sektöründeki Amerikan hegemonyası sebebiyle oradaki olumlu gelişmelere bağlı olunduğunun altını çizen Prestige Sinemaları Program Direktörü Cengiz Koyuncu, salgının henüz Türkiye'de görülmediği dönemde bile etkilerinin gişede hissedildiğini ve sinemalarda normalleşmenin 6 aydan önce olmayacağını söyledi (Box, 2020).

\section{Yöntem}

Avrupa'nın en çok yerli film izlenen endüstrisi olan Türk sinema endüstrisi doğrudan ve dolaylı olarak binlerce kişiyi etkilemektedir. Bu çalışmada Covid-19 süreci sonrası dünya ve Türk sinema endüstrileri genelinde belgesel kaynak taraması yapılarak Türk sinema endüstrisi özelinde yaşanan gelişmeler, sinema değerler zinciri bağlamında betimsel analiz yöntemiyle incelenmiştir.

Worthington (2011: 18-19) üçünü temel olarak kabul ettiği (Pre-Prodüksiyon, Prodüksiyon, Post -Prodüksiyon) sinemanın aşamalarını yedi başlık altında toplar:

1. Fikrin oluşumu

2. Finans

3. Pre-prodüksiyon (Yapım öncesi)

4. Prodüksiyon (Yapım)

5. Post-prodüksiyon (Yapım sonras1)

6. Dağıtım

7. Gösterim

Tüm bu aşamalar sinema endüstrisinin temel bileşenleri olmakla birlikte aynı zamanda bir değer zinciri oluşumunu sağlarlar. Değer zinciri (value chain), "bir hizmet veya ürünün, düşünsel gelişim noktasından başlayarak birçok üretim sürecinden geçen (fiziksel değişim ve birçok değişik üretici hizmetlerinin katkısını da içermek üzere) ve nihai tüketiciye erişimine, kullanım sonrasına dek bir parçası olduğu tüm operasyonları açıklayan bir kavramdır" şeklinde tanımlanabilir (Kaplinsky ve Morris, 2010: 4).

Sinemada temel olarak değerler zinciri "Yapım öncesi, Yapım, Yapım sonrası ve DağıtımGösterim" başlıkları altında toplanmaktadır. Çalışmada bu başlıklar ana kategoriler olarak belirlenmiştir. Covid-19 ve sinema bağlamında güncel kaynaklardan belgesel kaynak tarama yöntemi ile veriler toplanmıştır. Elde edilen veriler, belirlenen değerler zinciri kategorilerine göre sinıflandırılmış̧ır. Son olarak betimsel analiz yöntemi ile Türk sinema endüstrisinin Covid-19 sonrası yaşadığı süreç analiz edilmeye çalışılmıştır.

Betimsel analiz "belirlenmiş bir konu hakkında yapılan çalışmaların taranarak saptanması", "genel olarak eğilimlerinin belirlenmesi, araştırma sonrası elde edilen sonuçların tanımlayıcı olarak değerlendirilmesini kapsayan planlı çalışmalar bütünü” şeklinde tamamlanmaktadır (Çalık, Ünal, Coştu ve Karataş, 2008). Derinlemesine analiz gerektirmeyen verilerin işlenmesinde betimsel analiz kullanılırken, elde edilen verilerin daha yakından incelenmesi, bu verileri açıklayan kavram ve temalara ulaşılması gerektiğinde içerik analizi kullanılır. (Kurt, 2018: 35) Betimsel analizin, 
araştırmacılar için çalışmak istedikleri farklı olgu ve olaylar hakkında özet bilgi elde edebilmeleri için sıklıkla başvurulan bir yöntemdir (Büyüköztürk, Çakmak, Akgün, Karadeniz ve Demirel, 2008). Analiz sonucunda elde edilen bulgular ayrıntılı bir biçimde betimlendikten sonra araştırmacı bulgular ilgili yorumları sunabilir (Yıldırım ve Şimşek, 2005: 56).

Çalışmada, Covid-19'un sinemada meydana getirdiği kriz, Türk Sineması'nda yaşanan gelişmeler, sorunlar ve çözüm yolları ile birlikte tartışılmaktadır.

\section{Yapım Öncesi Türk Sineması}

Yapım öncesi, Türk sinema endüstrisinin krizi diğer aşamalarına göre en az hasarla atlatan aşamasıdır. Çekimlerin durması, projelerin ertelenmesi mevcut projelerin değerlendirildiği, aday projelerin gözden geçirildiği, yeni fikirlerin geliştirildiği yapım öncesi çalışmalarına geniş zaman ayrılmasına yardımcı olmuştur. Endüstrinin rekabeti yüksek, hızlı akışı içerisinde çok yoğunlaşılamayan bu aşamada pek çok proje gözden kaçabilmektedir. Pandemi sürecinde yapım şirketleri, yaratıcı ekipleri ile birlikte ellerindeki projeleri detaylandırmış, yeni proje fikirleri geliştirmiş, kendilerine sunulan projeleri zaman sınırı olmadan rahat bir zaman diliminde okuma ve değerlendirme firsatı bulmuşlardır. Okur, yapımcıların özellikle proje geliştirmek için masa başı çalışması için hiç olmadığı kadar zamanları olduğunu söylemektedir (Box, 2020). Yönetmen Ezel Akay, çekimlerini ertelediği fillminin senaryosu üzerinde yoğunlaşmıştır (Estukyan, 2020).

TAFF kurucu ortağı Cemal Okan da bu süreçte online ortamda pek çok proje üzerinden çalıştıklarını belirtmektedir (Box, 2020): “Önümüzdeki sene yapmayı planladığımız dört projemizin bütün çalışmalarını aşağı yukarı sürdürüyoruz. Ölümlü Dünya ekibi devam filminin senaryosu üzerine çalışıyor, senaryosu hazır olan Sen Yaşamaya Bak filminin cast çalışmaları sürüyor. Cinnet 2'yi yapmayı planlıyorduk, o belki seneye kalabilir... Bergen projesiyle ilgili de sanat ekibi son rötuşlarını yapıyor, senaryo çalışmaları da devam etmekte..."

Yapım öncesi, şirketlerden bağımsız olarak film projeleri üreten sinemacılar ve senaristler için de fikirlerini geliştirip olgunlaştırma dönemi olmuştur. Film projelerinin eksikleri giderilip dramatik yapıları güçlendirilebilir. Üretimin azaldığı ve gelecek süreçte çok daha az bir sayıda yapımın gerçekleşeceği düşünülürse normalleşme döneminde iyi çalışılmış projeler bir adım öne çıkacaktır. Bununla birlikte projelerin daha etkili sunumları ve pazarlanması için de geniş bir zaman dilimi ortaya çıkmıştır. Özellikle inovatif fikir ve projelerin tasarlanması için uygun bir ortam mevcuttur. Yönetmen Atalay Taşdiken de Covid-19 gibi bu tür kriz ortamlarında yaratıcı fikirlerin ortaya çıkabileceğini karantina sürecinin bu fikirlere zemin sağladığını ifade etmektedir (Bulovalı, 2020).

Cast ekibi projeler için deneme çekimlerini izleyerek, adayları inceleyerek oyuncu seçimleri yapmış; teknik ekip çekim dönemlerinde yoğun olarak kullanılan ve yıpranan teknik cihazların bakım, onarım ve temizliğini gerçekleştirmiştir.

Tanıtım, reklam ve arşiv çalışmaları üzerine yoğunlaşılıp endüstrinin ihmal edilen pazarlama kısmı daha aktif hale getirilmiştir. Web siteleri ve sosyal medya hesapları gözden geçirilerek eksikler giderilmiş, yeni içerikler üretilmiştir Vizyonu ertelenen filmler için reklam ve tanıtım dosyaları, projeler hazırlanmıştır. Çünkü her yönden zorlu geçecek vizyon dönemine hazırlıklı girilmelidir.

\section{Yapım Așamasında Türk Sineması}

Yapım aşaması sinema endüstrisinin değerler zinciri içerisindeki kilit aşamalardan biridir. Kendi dinamikleri üzerinde sağlam duramayan Türk sinema endüstrisi, oldukça kırılgandır. Mısır Savaşları krizi bunun en büyük göstergesi olmuştur. Sinema Televizyon Sendikası Başkanı Tuba Ataç, pandemi ile birlikte reklam, dizi ve sinema sektörlerinde 100 civarında seti durduklarını ifade etmiştir (Sinema-TV, 2020). İlgili sektörlerin \%98'i uyarıları dikkate almıştır. Çekimlere ara verilip yeni projelerin çekimlerinin durması Türk sinema endüstrisinde öncelikle büyük bir işsizliği sebep 
olmuştur. Endüstrinin büyük çoğunluğu özellikle kamera arkası işçileri freelance çalışmaktadır. Setler durduğunda veya ara verdiğinde doğrudan ekonomik kayba uğramaktadırlar. Sigortaları da çalıştıkları süre boyunca ödendiği için hem ekonomik hem de sağlık yönünden büyük bir sorun ile karşı karşıya kalmışlardır. Sinema emekçilerinin yapım sonrası ile ilgilenmediğini belirten Yönetmen Ulaş Yiğit Ülker, önemli olanın onlar için setlerin devam etmesi olduğunu söylemektedir (Zeybek 2, 2020).

Sinema endüstrisi dışında gelir sağladıkları televizyon ve reklam sektörlerinin de krizden etkilenmesi sinema işçilerinin çözüm yollarını da daraltmıştır. Sinema işçileri Covid-19 krizi öncesi de sigortasız çalıştırma, uzun mesai saatleri, zamanında ödenmeyen ücretler, sağlıksız çalışma ortamları ve son yıllarda sıkça dile getirilen mobing ve tacizler gibi pek çok sorun ile mücadele etmekte idi. Yeni dönemde sınırlı üretim yapılacağı düşünüldüğünde azalacak işgücü ihtiyacı sebebiyle pek çok sinema işçisi ilerleyen yıllarda işsiz olarak hayatına devam edecektir.

Sektör çalışanlarına en önemli desteği Netflix verdi. Netflix, Türkiye'de sektör çalışanlarına İstanbul Kültür Sanat Vakfı ve Sinema Televizyon Sendikası işbirliği ile 4 milyon TL'lik katkı sağladı (Hatunoğlu, 2020). "COVID-19 Sinema ve Televizyon Sektörü Desteği" adıyla gerçekleştirilen desteğe serbest çalışanlar da dahil olmak üzere Türkiye çapında prodüksiyonların durmasından olumsuz etkilenen kamera arkası çalışanları başvurdu. Bu kapsamda kamera, ışık, ses, sanat yönetimi, makyaj, kostüm tasarımı ve ulaşım gibi farklı birimlerde asistanlık, koordinatörlük, operatörlük ve teknisyenlik gibi çeşitli görevler üstlenen sayısız çalışan yer almaktadır. Sektör çalışanlarına verdikleri hizmetlerden dolayı sunulan bu destek kapsamında bir defaya mahsus olarak dağıtılacak kişi başı destek ise $2.500 \mathrm{TL}$ olarak belirlendi. Desteğin yönetimini ve dağıtımını İKSV ve Sinema Televizyon Sendikası yaptı. Netflix, ayrıca platformuna bağlı sektör çalışanları için 150 milyon dolarlık bir fon hazırlamıştı.

Yeni film üretilmediği zaman zincirleme olarak hem maddi hem insani düzeyde endüstri de olumsuz etkilenmeler olmaktadır (İstanbul, 2020). Çekim öncesi çalışmaları sayılmaz ise set başladıktan sonra 4-6 ayda neticelenen bir süreç olduğunun altını çizen TAFF Pictures ve TIMS\&B Productions Kurucu Ortağı Timur Savc1, kritik bir dönemde olunduğunu, yazın veya sonbaharda film çekilmez ise 2021'in ilk yarısında yeni filmlerin vizyona girmeyeceğini belirtmektedir (Bayrak, 2020). Başka bir açıdan süreç böyle devam ederse 2021 yılında sinema salonlarında yoğun olarak yabancı filmler gösterilecek, bazı filmlerinde gösterimleri uzun sürecektir. Ülker'in ifadesiyle yazın film çekilmez ise kış biraz daha sakin ve televizyon başında geçecektir (Zeybek 2, 2020).

Endüstrinin çok kötü durumda olduğunu vurgulayan Yıldırım da Savcı ile benzer görüşleri dile getirerek eğer film çekilmez ise ancak 2021'in Kasım ayında endüstrinin kendine gelebileceğini ancak bu süreçte pek çok alışkanlığın da değişmiş olabileceğini ifade etmektedir (Karayel, 2020).

Büyülü Fener Sinemaları İşletmecisi İrfan Demirkol sinemaların işlevsel hale gelmemesinin yeni film üretimini engellediğini söylemektedir: "Sinema salonlarının eylülde açılarak tam olarak işlevsel hale 1 Ekim'den itibaren geçecek olması yapımcıları yeni film çekmeleri konusunda tereddütte bırakıyor. Çünkü karantina nedeniyle gösterimi yarım kalan ve vizyon tarihi ertelenen birçok Türk ve yabancı film bulunuyor. Sinema salonlarının açılmasıyla gösterime girecek bu filmler vizyon takvimini oldukça sıkıştıracak." (Çalışkan 2, 2020)

Endüstrideki belirsizliğin üretime negatif olarak yansıdığı yorumunda bulunan Okur'a göre ise kriz ortamında yapım şirketlerinin risk almayı istemeyecek ve haliyle film üretimi azalacaktır (Box, 2020).

Aslan ise bir yapımcının istediği bir projeyi mutlaka hayata geçireceğini şu anda Türk sinema endüstrisinin hazırda beklediğini ifade etmektedir (Çalışkan, 2020). Ona göre bu süreç bir firsat olup kaliteli işlerin çıkmasına zemin sağlayacaktır: 
"Sinema sektörü de diğer tüm sektörler gibi bu süreçten etkilenecek ve dönüşmeye zorlanacak. Yapımcılar ve film yatırımı yapan şirketlerin artık yıllık film adetlerinden ziyade seyirciyi evden çıkmaya ikna edecek, heyecanlandıracak kalitede işlerin peşine düşecektir. Yıllık vizyona giren yerli film sayılarında ciddi bir düşüş olacağını bilmekle birlikte film üretiminde artık risk almak istemeyen yapımcıların daha büyük titizlikle, daha iyi film yapmaya zorlanacaklarını ve bunun da sektörde ürün kalitesi anlamında olumlu bir dönüşüme sebep olacağını tahmin ediyoruz." (Çalışkan, 2020)

Yıldırım'ın çözüm önerisi ise büyük yapım şirketlerinden 7 ya da 8 filmin çekime başlamasıdır: "Benim iki filmim hazır; Gupse Özay ve Çağan Irmak ile hemen sete çıkabilirim. Temmuz'da birinin, Eylül'de diğerinin setine girmek istiyorum. 6-7 tane başka yapımcı arkadaşımız da sete girerse sektörü yukarı çıkartırız, salonlar ayakta kalır, yapımcı da mutlu olur." (Karayel, 2020)

\section{Pandemi Sonrası Film Çekmek}

Okur'a göre hem yapım şirketlerine hem çalışanlara ekonomik anlamda büyük zarar veren setlerin durması ile birlikte içeriklerin tükenmesi de ayrı bir sorun (Box, 2020). Normalleşme süreci ile birlikte 1 Temmuz'da sinema salonlarının açılması planlanmaktadır. Yeni sezonu uzmanların "salgın, ağustos ayı içinde biter" görüşünden yola çıkarak şekillendiren BKM, TAFF Pictures, TR 4033 Productions yeni sezon için hazırlıklarına başladı (Çalışkan 2, 2020). Şahan Gökbakar, Ezel Akay, Murat Şeker, Erdal Murat Aktaş gibi yönetmenlerde yeni filmleri için çekim takvimi belirledi.

Pandemi çekim şartlarını da etkiledi. Sinema Televizyon Sendikası, Türk Tabipler Birliği, TESIYYAP gibi meslek birlikleri ve sağlık örgütleri, sektör paydaşları ile birlikte TC Sağlık Bakanlığı ve Koronavirüs Bilim Kurulu'nun tavsiye ve talimatları doğrultusunda çekim ortamlarında uyulması gereken kurallar ve alınması gereken tedbirler ile ilgili kitapçıklar ve kılavuzlar hazırladı. Bu kitapçık ve kılavuzlarda set ortamının ve cihazların önceden dezenfekte edilmesi, çalışanların sağlık kontrolünden geçmiş olması, maske ve sosyal mesafe kuralı zorunluluğu, toplantı yasakları, ambulans bulundurulması, bu kuralları denetleyen uzman bir pandemi ekibinin bulunması, servis araçlarında kalabalıkların oluşturulmaması gibi çok çeşitli kurallar yer alıyor.

Özgül (2020), Türk Tabipler birliğinin hazırladığı çalışma hakkındaki görüşleri şunlardır: "Bu metin, sinema ve dizi setlerindeki hijyen standartlarına, yemek koşullarına, çay ve kahve servisine, çalışma saatlerine ve ulaşım yöntemlerine dair pek çok konuya değinen kapsamlı bir çalışma. Pratikte oldukça başarılı gözükse de uygulama konusunda sektörü ve sektör çalışanlarını ne kadar koruyabileceği ise tartışllabilir."

Çalışkan'da oluşturulan set kurallarının yeni film çekmeyi zorlaştırdığını söyleyip şu örneği veriyor: "Örneğin kurallarda çalışanların bir otomobile iki kişiden daha fazla kişinin binmemesi şartı bulunuyor... Setlerde ortalama 70 kişinin çalıştı̆̆ düşünülecek olursa ulaşım için en az 35 otomobil gerekecek. Bu kadar çok otomobilin olması maliyeti arttıracağı gibi set bölgesinde oluşturacağı park sorunuyla çekimleri aksatacak. Ulaşım sorunu bile yapımcılar için başı ıaşına bir dert." (Çalışkan $2,2020)$

Türkiye'de sinema ve dizi setlerinde ortalama 100 kişilik kamera arkası çalışanı ve bu sayı haricinde oyuncuların, yardımcı oyuncuların, figüranların vs. bulunduğu oldukça hareketli, kalabalık bir ekip yer alıyor (Özgül, 2020). Hızlı hareket etmeyi gerektiren çekim ortamlarında, çoğu durumda yakın temas gerekiyor ve pek çok cihaz ortaklaşa kullanılıyor.

Sinema Televizyon Sendikası Yönetim Kurulu Üyesi Damla Kırkalı, bu zorlu süreçte sinema işçilerinin çalışma şartlarının insani bir seviyeye getirilmesi gerektiğinin altını çizerek şu noktalara vurgu yapıyor: "Yüksek riskli olan setlerde, kamera arkası ve önü çalışanlarının can güvenliğini güvence altına alabilmesi için birçok önlem alınması şart. Kalabalık, her yaştan insanın bulunduğu 
ve ekipman, malzeme sirkülasyonunun yoğun olduğu setlerin işleyiş anlamında büyük bir değişimden geçmesi gerekiyor. Günlük çekim sürelerinin kısalması gerekiyor." (Çalışkan 3, 2020)

En büyük sorun böyle kalabalık ve farklı uzmanlıkları olan ekibi kontrol etmek olarak ortaya çıkıyor. Zamanın çok önemli olduğu sette her dakika maliyet olarak hesap ediliyor. Bu şartlar altında hem çekim yapmak zorlaşacak hem de maliyet artacak, filmler çok daha uzun sürelerde çekilecektir. Yapım şirketleri bu sorunları aşmak için uygulanabilir çekim yöntemleri üzerinde çalışmalarını sürdürmektedir. "Stüdyolar bünyesine aldıkları salgın konusunda uzman danışmanlarla, yeni bir set dinamiği kurmanın yolunu aramakta. Ancak yüzlerce kişinin çalıştı̆̆ bir sette tüm önlemlere rağmen virüse engel olmak biraz zor görünüyor. Büyük stüdyolar, çekim ekiplerini çeşitli testlerden sonra platolarında kampa alıp setlerini dışarıyla ilişkisini keserek devam ettirmek üzerine de fikirler paylaşıyorlar. Kimi stüdyolar ise daha çok masada üretebilecekleri animasyon filmlerle sürecin etkilerini hafifletmek eğiliminde.” (Özgül, 2020)

Yapımcı Dağdeviren ise bu dönemde arthouse türündeki filmler konusunda bir patlama yaşanabileceğine işaret etmektedir: "Daha az insan, mekân, daha az ekip, daha az bütçe... Yani bu anlamda oralardan çok yaratıcı ve keyif aldıran işler ortaya çıkacağını düşünüyorum. $O$ zaman sinema salonuna girmeden, televizyon kanalı veya platformun yapacağı ödemeyle yaşayabilir ve yenisini üretebilir. Hatta bütçeli, nitelikli işler de ortaya çıkar." (Bulovalı, 2020)

$\mathrm{Bu}$ süreçte çekim süreci için iki çekim yöntemi ön plana çıkmıştır: Birincisi televizyon sektörünün hemen uygulamaya koyduğu "kendi kendine çekme yöntemi" yani oyuncuların aileleriyle çekim yaptığı yöntem. İkincisi ise "bütün oyuncuları ve ekibi karantinaya alarak çekim yapma yöntemi."

Covid-19 sonrası gerekli izinleri alıp çekimlere başlayan ilk film Son Uyanış oldu. 15 Temmuz Köprüsü’nde yapılan çekimler, Covid-19 sonrası setlerin alacağı görünümleri de ortaya çıkardı. Televizyon ve Sinema Filmi Yapımcıları Derneği'nin tavsiyelerine uyduklarını ifade eden filmin yapımcısı Sami Dündar çekimler hakkında şu bilgileri verdi: "Uzun bir süre kullanacağımız araçlar, kameralar, destek cihazları hijyenle tertemiz hale getirildi. Çalışma arkadaşlarımız da sağlık kontrollerini yapacak sete geldiler. Sette maske zorunlu sosyal mesafe zorunlu." (Türk, 2020) Bunun dışında sette TC Sağlık Bakanlığı onaylı profesyonel dezenfekte firması setin kurulduğu alanda ölçüm yaparak, tüm satıhları ve ekipmanları dezenfekte edilmiş, TC Sağlık Bakanlığı izinli özel bir ambulans yer almış, salgına karşı eğitimli sağlik personeli ve kurallara uyulmasından sorumlu pandemi ekibi denetim yapmıştır.

Sinema anlamında ilk çalışma oyuncu ve yönetmen Müfit Saçıntı tarafından gerçekleştirildi. Pandemi sürecinde yeni bir iş modeli geliştirerek sinemaya sosyal ağlar üzerinden devam etme kararı alan Saçınt1, YoutTube için "Maskeler de Düşer" filmini çekti (Sungur, 2020). YoutTube'un Premium uygulaması için çektirdiği filmlerden yola çıkan film, YouTube için çekilen ilk bağımsız film özelliğini taşıyor. Herkesin kendi evinde yaptı̆̆ı çekimler sonrası montajlanan film ilk olarak ücretsiz gösterilecek. Projenin sinema salonlarında gösterime göre daha kârlı olduğunu ifade eden Saçıntı, proje tutarsa her üç ayda bir film çekeceklerini ifade etti.

Covid-19'u beyazperde taşıyan ilk Türk filmi ise Corontina oldu. Tamamı İngilizce çekilen filmin kasım ayında vizyona girmesi planlanıyor. Korku türündeki film, dünyanın farklı ülkelerinden gelen, diş dünyayla iletişimleri olmadan, kameralarla dolu bir evde 1 milyon dolarlık büyük ödül için kıyasıya yarışan yarışmacıların başından geçenleri anlatıyor. Ödülden hayatta kalma mücadelesine dönüşen filmin yönetmenliğini Can Sarcan üstleniyor.

\section{Yapım Sonrası Türk Sineması}

Yapım sonrası aşaması da Türk sinema endüstrisinin rahatladığı bir aşama oldu. Bahar döneminde vizyon tarihi alan filmler, hazır hale gelmek için acele ederek pek çok detayı atlamakta, 
pazarlama çalışmaları için gerekli zamanı ayırmamakta idi. Vizyon filmlerinin ertelenmesi, filmlerin üzerlerinde daha detaylı çalışma imkânını doğurmuştur. Bu sayede kurgu, seslendirme, ses düzeltme, efektler ve bilgisayar uygulamaları titiz ve özenli bir şekilde yapılabilmiştir. Filmlerin geniş bir zaman diliminde izlenerek hata ve eksiklerinin görülmesi sağlanmıştır. Tüm kurgu senaryo bağlamında dramatik yapıya uygun olarak tekrar elden geçirilmiştir. Filmlerin görsel efektleri, müzikleri düzenlendi, renk düzenlemesi yapıldı, alt yazı çalışmaları tamamlandı. Vizyona istenen şekilde hazırlanan filmler görsel olarak daha güçlü hale getirildi.

Pandemi sürecinin bu bağlamda kendisi için işlevsel olduğunu ifade eden Yönetmen Taşdiken, çekimleri tamamlanan projesini bu süreçte rahat bir şekilde kurguladığını ifade etmektedir:

"Bu süreci, filmin planlarını izlemekle, kurgu hazırlığı yapmakla geçirdim. Bir anlamda belki benim açımdan avantajlı oldu. Kaba kurguyu süreç içerisinde steril bir ortamda sadece bir montajcıyla yaptım. Kendi adıma bu dönem rahat bir çalışma süreci oldu diyebilirim.” (Bulovalı, 2020).

Vizyon tarihi ertelenen 9 Kere Leyla filmi üzerinde çalışmalarına devam ettiğini ifade eden Yönetmen Akay, yapım sonrası anlamında başarılı bir süreç geçirdiklerini söylemektedir: "İlginç bir şekilde, bu süreci evde ama çok çalışarak geçirdim. Filmi biraz hızlı bitirmiştik, firsat bu firsat deyip renk, efekt, ses tasarımı, müzik gibi şeyleri bir daha ele aldık. Epey vakit aldı, biraz da zor oldu ama bitirdik." (Estukyan, 2020)

\section{Dağıtım ve Gösterim Aşamasında Türk Sineması}

Sinema salonlarının kapanması ile birlikte Türk sinema endüstrisi en büyük gelir kaynağından mahrum olmuştur. 150 milyar dolara yaklaşan sinema endüstrisinin üçte bir geliri hala sinema salonlarından elde edilmektedir (Yılmaz 3, 2020). Mart ayında kapanan 150 sinema salonunun bir daha açılamayacağı dile getirilmektedir (Aydemir, 2020). Aslan'ın ifadelerine göre Türkiye genelinde şu anda faaliyet gösteren sinema işletmelerinin \%40'1 bu kriz nedeni ile faaliyetlerine son verecek, kalan sinemalar ise salon eksiltme yöntemine gideceklerdir (Box, 2020). Bununla birlikte kültürel bellekte önemli yerleri olan bağımsız sinema salonları da kapanmanın eşiğine gelmiştir. Sinema Yazarı Nil Kural'a göre özellikle bu zorlu dönemde bağımsız sinemaların ayakta kalabilmesi için festivaller ve dağıtımcılar projeler geliştirmelidirler (Kural, 2020). 60 yıllık Rexx Sineması kapanırken, Kadıköy, Beyoğlu ve Karaca sinemaları mücadelelerine çeşitli yardım organizasyonları ve projeleri ile devam etmektedirler. Bu bağımsız sinema salonları farklı ve üretken çözüm yolları geliştirmişlerdir. Bunlardan en aktif olanı Beyoğlu Sineması oldu. Kapanma aşamasında iken üyelik projesi ve çeşitli organizasyonlar ile ayakta duran, Başka Sinema ile işbirliği içinde film gösterimlerine devam eden Beyoğlu Sineması, pandemi döneminin kriz ortamında abonelik sistemine dayalı 1989 isimli haftalık dijital sinema gazetesi çıarmaya başladı. Mail olarak abonelere ulaştırılan 1989, film eleştirileri, sinema tarihi, endüstrisi hakkında yazılar, söyleşiler ve önerilerden oluşan zengin bir içerik sunmaktadır. İlk ayında dijital 1989 gazetesi, 700'e yakın aboneye ulaştı (İleri, 2020). 1989 sadece bir sinema gazetesi değil, Beyoğlu Sineması çatısı altında oluşturmayı çalışılan sinema kulübünün ilk adımları olarak görülmektedir.

$\mathrm{Bu}$ oluşumu sinema kulübüne doğru eviren Beyoğlu Sinemas1, ayrıca fongogo üzerinden kitle fonlama yöntemi ile de destek toplamaya devam ediyor. Beyoğlu Sineması ile birlikte uyumlu bir şekilde mücadelesini sürdüren Kadıköy Sineması, koltuklara isim verme kampanyası ile pandemi sürecinin etkilerini azaltmaya çalışıyor. 1969 yılından beri açık olan İzmir'in en eski sinemalarından Karaca Sineması da ayakta kalabilmek için fongogo üzerinden kitle fonlama yöntemine başvurmuştur.

Vizyondaki filmlerin gösterimleri yarım kalırken 13 Mart'ta gösterime girmesi planlanan Müstakbel Damat, Aslan Hürkuş Kayıp Elmas, Malazgirt 1071 ve 20 Mart vizyon tarihli Adanış 
Kutsal Kavga filmlerinin gösterimleri ertelenmiştir. Gösterim planı yapılan filmlerde büyük zarar uğramıştır.

Pervasız Yapım'ın kurucularından M. Serdar Fırat, gösterimi ertelene Müstakbel Damat filmleri ile ilgili olarak şu değerlendirmelerde bulunmaktadır: "Müstakbel Damat filmimiz ' 400 lokasyon' gibi şahane bir sinema sayısı ve 'genel İzleyici' sınıflandırmasıyla vizyona girmek üzereydi kriz başladığında... Tanıtım anlamında tüm yatırımların yapıldığı bir noktadaydık. Bu kadar büyük prodüksiyonlu bir yapım süreci sonrası çok büyük bir maddi zarar var tabii ki, manevi kısmını ise anlatmaya gerek yok zaten.” (Box, 2020)

\section{Dijital Platformlar Yeni Gösterim Mecrası}

Sinema salonlarının kapanması ile birlikte gösterim mecrası olarak dijital platformlar ön plana çıkmıştır. Son yıllarda yükselişe geçen ve seyir kültürünü değiştirdiği ifade edilen dijital platformlar evde kalma zorunluluğunda zengin ve başarılı içerikleri ile yoğun bir ilgi görmüştür. Disney+'in, şubat ayında 28 milyon olan abone sayısı nisan ayında 50 milyonu geçti, Disney'in bir diğer dijital platformu Hulu'nun ise 30 milyon abonesi bulunuyor (Küstür, 2020). Amazon Prime'in 150 milyon abonesi bulunuyor. (Disney+, 2020) Netflix'in ilk çeyrek sonu itibarıyla ulaştığı toplam abone sayısı ise 182,9 milyon oldu. Yerli dijital platformlarından Blu TV'de pandemi sürecinde abone artışı yaşamış, Puhu TV'nin izlenme oranları artmıştır.

İnsanların evlerinde kalması Aydemir'e göre iki zorunlu nedene yol açtı: "Genel anlamda dizilerin yeni bir 'altın çağ'a gireceği, üretimin daha çok bu alana kayacağı 1 ve salgınla birlikte yükselişe geçen online pazarındaki büyümenin devam edeceği..." (Aydemir 2, 2020) Virüsün etkili olduğu yılın ilk çeyreğinde, dijital platformlara üye olanların sayısı geçmiş dört yıla oranla yüzde 15,8 artış göstermiş, ev sinema sistemlerine talep yüzde 8'e çıkmıştır (Koronavirüsün, 2020).

Pandemi sürecinde bağımsız filmlerin dağıtımını gerçekleştiren Başka Sinema Türkiye'nin ilk yerli dijital platformu Blu TV ile işbirliğine gitti. Başka Sinema "Başka Çarşamba" konsepti ve "Başka Sinema" filmlerini dijital platform üzerinden "kirala-izle" şeklinde gösterime soktu. Tek bir film 19.99 TL'den 24 saat boyunca sadece bir defa izlenebilmektedir. Türkiye'de ilk kez gerçekleştirilen bu işbirliği çerçevesinde Bozkır, Genç Ahmed, Kural Dışı ve Yabancıların Nezaketi filmleri seyirci ile buluşmuştur. Gösterimlerden elde edilen gelirin bir kısmı ise Başka Sinema'nın anlaşmalı olduğu sinema salonlarına aktarılmıştır. Ancak seçilen filmler arasında 8 Nisan'da projenin ilk gösterimi olan Bozkır filmi gibi vizyona girmeyen bazı filmlerin olması dünya sinema endüstrisinde de tartışılan bir sorunu da gündeme getirmiştir. Sinema Kanunu'nda yapılan son değişiklik ile 30926 sayılı kanuna göre Türkiye'de vizyona giren filmler 5 ay sonra dijital platformlarda, 6 ay sonra ücretsiz yayın yapan platformlarda gösterilebilmektedir. Başka Sinema'nın bu kanuna uymaması Sinema Salonu Sahipleri Derneği (SİSAY) tarafinda tepkiyle karşılanmış ve set bir şekilde eleştirilmiştir. Bu tür uygulamaların sinema salonlarına zarar vereceğinin ve iş modelini bozacağının altı çizilmiş̧ir. Ülker, üretimin az olduğu Türk sinema endüstrisinde SiSAY'ın haklı olabileceğini ama tavırlarının samimi ve yapıcı olmadığını ifade etmektedir (Zeybek 2, 2020).

Kriz ortamında çıkış arayan yapım şirketleri ve dağıtımcılar için dijital platformlar alternatif bir gösterim mecrası oldu. Bunun endüstrinin doğal akışı içerisinde olağan bir süreç olduğunu belirten sektör paydaşları, dijital platformların artık görmezden gelinemeyeceğinin altını çiziyor. Sinema yazarı ve eleştirmen Aslı Ildır'ın belirttiği gibi "vizyon” kavramının sinema salonunun dışına taşarak Netflix gibi dijital platformları da kapsar hale gelmesi, geçmişte bir istisna olan bu durumu yeni bir tür "normalin" parçası haline getirmiştir (Özdemir, 2020).

Insignia Yapım'ın Kurucu-Yönetici Ortağı Dorukhan Acar'a göre günümüzde üretilen içeriğin maliyetini bir mecra tek başına karşılayamadığından dijital platformlar, ana akım kanallar ve dağıtım şirketlerinin birlikte üretim yapmaları doğaldır. İşbirliklerine haksız rekabet 
yaratmadıkları, içerik özgürlüğüne ve serbest piyasaya engel olmadıkları takdirde olumlu yaklaşılmalıdır (Yılmaz 4, 2020).

Teknik alt yapıları, geniş hedef kitlesi ve zengin içerikleri ile endüstrinin önemli kollarında biri olan dijital platformlar, covid-19 krizi ile daha görünür oldular. Türk Sineması'nın bu durumları önemsemediğini belirten Erkılıç, Covid-19 pandemisinin bu süreçte katalizör işlevi gördüğünü söylemektedir (Yılmaz, 2020). Dijitalin daha da ivme kazanacağını belirten İstanbul Film Festivali Direktörü Kerem Ayan'a göre birçok kurum iş yapma tarzlarını da değiştirecektir (İstanbul, 2020).

Dijitalleşmenin olağan süreci sonucu endüstri içine dâhil olan dijital platformlar, klasik değerler zincirini kırarak gösterim aşamasını çeşitlendirmektedir. Yeni Değer Zinciri’nde sinema salonlarının yine ilk sırada ama internet/dijital platformlar yükselişte olduğunu belirten Erkılıç, "Yeni Medya İş Modeli" olarak tanımladığı bu sistemde seyircinin sinema salonundan kopmadan dijital platform pencerelerine yöneldiğini ve seyir deneyiminin dijitalleşmeyle birlikte çoğullaştığını ifade etmektedir. (Yılmaz, 2020). Prof. Dr. Akbulut'ta, online platformların düşmanlaştırılmadan seyir pratiğini çoğullaştıracak etik, hakkaniyetli çabaların desteklenmesi gerektiğini ifade etmektedir (Zeybek, 2020).

Dijital platformlar seyir kültürünü değișime uğrattığı bir gerçektir. Seyir kültürü toplu bir eylemden daha küçük gruplara, aile için ve bireysel bir seyir eylemine dönüşmektedir. Büyük perde ve etkili ses sisteminden ev konforunda daha küçük ekranlarda filmler seyredilir hale gelmektedir. Sinema salonların görsel ve ses anlamında etkileyiciliği ve eşsiz atmosferine karşıllk dijital platformlar rahatlık, bütçe olarak daha uygunluk, istenilen zaman ve mekân izleme olanağı birlikte zengin ve kaliteli içerikler sunmaktadır. Dijital platformlar sayesinde daha geniş kitlelere daha hızlı bir şekilde ulaşmak mümkün olabilmektedir.

Bağımsız filmler için dijital platformlar daha iyi bir gösterim mecrası olabilir. Çünkü bağımsız filmler, çok az salonda çok az süre ile gösterim şansı bulmaktadırlar. Gösterilen salonların sinema seyircisinin yoğun olarak gitmediği salonlar olması, özenli hatta hiç tanıtım ve reklam çalışmasının yapılmaması bağımsız filmlerin çok düşük sayıda izleyici ile buluşmasına sebep olmaktadır. Filmler seyirci ile buluşamadığı gibi maddi olarak da yapımcısına herhangi katkı sağlamamaktadır.

Yönetmen Ülker, şartların değiştiği sinema endüstrisinde sinemayı yeniden şekillendirecek olan dijitalleşme karşısında çözüm olarak kendi dijital platformlarımızın oluşturulmasını önermektedir Zeybek 2, 2020).

Yapımcı Elif Dağdeviren ise sinema salonlarının tamamen devreden çıkarılmasının film yapımcılarını mecburen platformlara ve televizyon kanallarına bağlı hale getireceğini ve hiç bir televizyon ya da platformun kendi yapımı değilse, izlenen kaliteli içerikleri finanse edebilecek güçte olmadığını söylüyor (Bulovalı, 2020).

Akay, değişen seyir kültür ile birlikte yeni oluşan bilgili ve bilinçli sinema seyircisinin Türk sinema endüstrisinde kaliteli projelerin hayata geçirilmesine zemin hazırlayacağını savunuyor: "Film hikâyesi izleme kültürünü değiştiriyor. Hem de olumlu anlamda. Türkiye'de çekilen birçok sinema filmi bu platformlardaki filmlerden geride kalır. O platformlardaki filmler sofistikasyon açısından, estetik açıdan, teknik açıdan çok daha ileride ve bunu seyretmeye alışmış bir kitle doğuyor. Bu, sektörü motive edecek bir şey. Biz de iyi sineme yapmak zorunda kalacağız. İyi sinema yaptığımız takdirde yeni seyirci doğmuş diye bakmalıyız.” (Estukyan, 2020)

\section{Pandemi Sonrası Sinema Salonları}

Film Yapımcıları Meslek Birliği Başkan Yardımcısı Nazif Tunç'un belirttiği gibi Beyoğlu Gloria (1400 koltuklu), Çemberlitaş Şafak (1350 koltuklu) ve İpek Sinemaları'nda (1350 koltuklu) 
neredeyse 1500 kişiyle aynı anda film seyredilen sinemanın altın çağları geride kalmıştır (Yılmaz 2, 2020). Sinema sosyalleşme, birlikte olma, seyre özel mekân olma avantajları ile Covid-19 krizinden etkilense, dijital karşısında güç kaybetse de tamamen kaybolmayacaktır. Akay'a göre büyük ekranda sinema filmi izlemek kesinlikle arzu edilecek bir şey haline gelecektir. Çünkü sinemanın büyüsü başkadır. "Kulaklıklarla cep telefonundan, bilgisayar ekranından müzik dinliyoruz halbuki o müziklerin miksajları, aranjmanları için neler yapılıyor. Ancak büyük bir konserde ya da sinema salonunda o müziğin gerçek değerini hissetmek mümkün. Bunu özlemeyecek mi insanlar? Ben, özleyeceklerini düşünüyorum.” (Estukyan, 2020)

Sinema salonları normalleşme süreci ile birlikte 1 Temmuz'da kapılarını sinemaseverlere açacak. Ancak sinema salonlarını pek çok sorun bekliyor. Türk Sineması için "ölü sezon" olarak tanımlanan yaz aylarında ${ }^{1}$ sinema salonlarının doluluk oranı ortalama $\% 13$, kış aylarında ise doluluk oranı ortalama \% 35'tir (Çalışkan 4, 2020). İnsanların tatile çıktığı, daha çok dışarda olmaya tercih ettiği bu dönemde sinemalarda çok az film ve genelde yabancı filmler gösterilmektedir. Prestige Sinemaları Program Direktörü Cengiz Koyuncu yaz döneminde sinemaların açılması halinde içerik sıkıntısı yaşanacağına işaret etmektedir (Box Office, 2020). Geçen yaz da kriz olmamasına rağmen sinemalar salon kapatarak faaliyetlerine devam etmiştir.

Demirkol, sinema salonlarının açılması için 1 Temmuz'un çok erken bir tarih olduğunu söylemektedir. Ona göre bu dönem için yeterli içerik olmadığı gibi gerekli tedbirlerde alınamayacaktır. Salonlar, seans sayısı ve kapasite sınırlamalarıyla eylül ayı içerisinde ancak ısınma turu atabilecektir. Sinema salonlarının tam anlamıyla açılışı için ise en uygun tarihin ekim ayıdır (Sinema Salonu, 2020).

TME Films Pazarlama Direktörü Sultan Duranay, sönük geçecek yaz ayının ardından Covid19'un etkilerini sonbaharda daha da çok hissedileceğinin altını çizerken etkili duyurular, salona belli sayıda insan almak, uygun oturma düzeni ve çeşitli kampanyalar ile bunun önüne geçilebileceğini belirtiyor (Box, 2020).

Sinema salonları faaliyet geçse de normal süreçte olduğu gibi bir işleyişe sahip olamayacak. Özellikle AVM sinemaları tam kapasite ile çalışamayacak. Çünkü hem AVM'lere girişi sınırlı hem de sinema salonlarına giriş sınırlı durumdadır. Sinema salonları oturma düzeni sosyal mesafe kuralları gereği olacağı için salonların kapasiteleri yarı yarıya düşecektir. Özellikle büyük şehirlerde maske zorunluluğu ve diğer tedbirler, rahat bir seyir zevkini zorlaştıracaktır. Periyodik olarak dezenfeksiyon yapılması, gerekli kontroller için personel istihdamı ve artan hijyen giderleri ekstra mali yük getirecektir. Kampanyalı bilet satışlarının yapılamaması ile birlikte sinema biletlerinin fiyatlarında bir artış olma ihtimali vardır. Saçıntı, sinemaların normalleşme sürecinde çok sağlıklı işlemeyeceği düşüncesini taşımaktadır. Sinemaların yarı kapasite ile çalışmasının bilet fiyatlarını yükselteceğini dile getiren Saçıntı, sinema seyircisinin ekonomik olarak bunu karşılamayacağını söylemektedir. (Çalışkan 3, 2020) Diğer taraftan işletmeciler seyirciyi sinemaya teşvik etmek amacı ile biletlerde indirime de gidebilirler.

Covid-19 krizinin uzun sürmesi halinde dağıtım şirketlerinin zorlanacağını belirten Aslan, yerli içeriğin hakim olan Türk sinema endüstrisinde böyle bir durumda sermaye gücü az olan, tekli sinemalar ve küçük sinema zincirlerini zorlayacağını, sinema kapanmaları ile yeni birleşmelerin gerçekleşebileceğini ifade etmektedir (Box, 2020).

Akbulut sinema salonlarının kimliklenme ve sosyalleşme olanağı sunduğu belirterek kültürel miras olarak korunması gerektiğinin altını çizmektedir: "Sinema salonlarının kendisi, mimari özellikleri hem somut kültürel miras hem de sunduğu sinema deneyimleri nedeniyle somut olmayan kültürel miras. Kapsamlı kültür politikalarında sinema salonlarının bu niteliklerinin farkında olarak

\footnotetext{
${ }^{1}$ Yaz aylarında televizyon sektörü de pek çok dizi ve programına ara vermekte, tatile girmektedir. Genel olarak yayın dönemi eylül ve haziran aylarını kapsamaktadır.
} 
onları korumak ve geliştirmek oldukça önemli. Ayrıca sinema salonları, seyirci olarak bizlerin belleklerinde de önemlerini koruyor. Bir yere ait olma, kimliklenme ve sosyalleşme olanağ 1 sunuyor." (Zeybek, 2020)

Sinema salonları için bir diğer önemli sorun ise hızla yayılan ve ölümlü sonuçlara neden olan pandeminin getirdiği korku ile seyircilerin sinemaya gitmeme ihtimalidir. Aslan'a göre endüstriyi bekleyen en büyük problem içerik sıkıntısı ile birlikte seyircilerin tekrar sinemaya dönüşünün zaman almasıdır (Box Office, 2020). Avşar Sinemaları Genel Koordinatörü Murat Çiçek’te kapalı bir mekân olan sinema salonlarından insanların kendilerini koruma psikolojisi ile uzak duracağını söylüyor (Box Office, 2020). CGV Mars Cinema Group Dağıtım Genel Müdürü Serdar Can ise tam tersi bir görüş öne sürmektedir. Ona göre 2015 yılında MERS virüsü sonrası gösterime giren Jurassic World'te olduğu gibi sinema salonların açıldıktan sonra insanlar sosyalleşme ihtiyacı gereği sinema salonlarına yoğun ilgi gösterecek (Box, 2020).

Savc1, Covid-19 krizinin gösterim bekleyen filmler için bir firsatta olabileceğini belirtiyor: "Bu sene vizyon bulamayan filmler gelecek sene rekabetsiz ortamda sinemayı özleyen izleyiciyle daha yoğun bir buluşma yaşar." (Bayrak, 2020)

Pandeminin geçmişten bugüne getirdiği gösterim mecrası ise arabalı sinemalar oldu. ABD'de 1930'larda, Avrupa'da ise 1950'lerde başlayan arabalı sinema trendi güvenli bir film seyretme yolu olarak popüler hale geldi. Saçıntı'ya göre yazın ölü sezonunda sadece arabalı sinemaların faaliyet gösterebilecektir; bunuda hayata geçirebilecek olanın belediye ve devlet kurumları olduğunu ifade etmektedir. Çünkü bu organizasyonlar için şehre yakın büyük ve organize alanlara ihtiyaçlar vardır (Çalışkan 3, 2020). Dünya geneline göre biraz daha geç olarak Türkiye'de haziran ayında başlayan arabalı sinema gösterimleri İstanbul, Bursa, İzmir, Antalya, Nevşehir, Kocaeli, Elazığ, Kayseri gibi pek çok şehirde belediyeler tarafından hayata geçirilmiştir. Yazlık ve açık hava sinemaları ise alternatif biri gösterim mecrası olarak yeniden hayata geçirilebilir. TIMS\&B Productions Kurucu Ortağı ve CEO'su Burak Sağyaşar, nostalji de yaparak açık hava sinemalarının tekrar gündeme getirmenin yaz dönemi için uygun olacağını ifade ediyor (Bayrak, 2020): "İstanbul'un en eski açıkhava sineması, ya da o zamanki tabirle bahçe sineması ise, 1913'te Şişli Halaskârgazi Caddesi'nde Eski Osmanbey Bahçesi adıyla açılır. Bir yıl sonra 1914'te açılan ve sonradan Sefa Bahçesi adını alacak olan Erenköy Sineması da aynı zamanda Anadolu yakasının ilk sineması olma özelliğini taşıyor." (Evren, 1996: 86)

Yazlık sinemaların en yoğun ilgi gördüğü 1960'lı yıllarda İstanbul'da 160'a yakın yazlık sineması olduğu, bunların çoğunun 1970'lerin ortasına kadar faaliyetlerini sürdürdüğü bilinmektedir (İleri 2, 2020).

\section{Film Festivalleri ve Yarışmalar}

Sinema filmlerinin kendini gösterme imkânı bulduğu, son durağı film festivalleri sektörün işleyişinde ayrıcalıklı bir yere sahiptir. Popüler sinema dışındaki hikâyelerin izlenebildiği festivaller, yurt içi ve yurt dışından pek çok sektör paydaşını ve sinemaseveri bir araya getirmektedir. Sinema kültürünün ortak seyir zevki yanında festivaller, pazarlama, tanıtım, proje geliştirme bağlamında da büyük öneme sahiptir. Sinema birikiminin artmasına yardımcı olan festivaller aynı zamanda genç sinemacıların sektör ile tanışmalarına, bağlantılar kurmalarına, bilgi birikimlerini arttırmalarına fırsat vermektedir.

Covid-19 krizi dünyada olduğu gibi Türkiye'de pek çok festivalin iptal edilmesine sebep olmuştur. Bazı festivaller ise online olarak etkinliklerini ve gösterimlerini gerçekleştirmişlerdir.

39. İstanbul Film Festivali (10-21 Nisan), 3. SUFISİN (4-7 Haziran), 12. TRT Uluslararas1 Belgesel Günleri (4-8 Haziran) iptal edildi. 16. Çocuk Filmleri Festivali (23 Nisan), İşçi Filmleri Festivali (1-7 Mayıs), 23. Uçan Süpürge Kadın Filmleri Festivali (7-14 Mayıs), 13. Documentarist İstanbul Belgesel Günleri (6-16 Haziran), 18. Uluslararası Gezici Filmmor Kadın Filmleri Festivali 
(12-22 Haziran) ve Uluslararası Göç Filmleri Festivali (14-21 Haziran), online olarak gerçekleştirilmiştir. Gösterim ve etkinlikleri dijital ortama taşınmıştır.

Akay festivallerin önemini şu sözleri ile dile getirmektedir: "Festivallerin yaşaması hem izleyiciler için hem de sinema sektörü için çok önemli. Bu sene festivallerin olmaması, festivallere zarar verecek bir şey çünkü onlar da oradan gelen çeşitli sponsorluk gelirleriyle yaşıyorlar. Yine de sinema sektöründe en az festivaller etkilenecek. Bence bir yıllı ğına bu zararı karşılayabiliriz. Başka yerden kaynak bulurlar, belki film seçkileri hazırlarlar, ücretli izletme yaparlar...” (Estukyan, 2020)

Bu yıl yapılamayan İstanbul Film Festivali, Köprüde Buluşmalar'ın 15.'sini 14-17 Nisan tarihleri arasında online olarak gerçekleştirmiş, farklı projeleri ile seyircisini online olarak buluşturmuştur. İlk olarak festivalin düzenlenmesi gereken tarihlerde festivalin ödüllü filmlerinden oluşan seçki MUBI'de gösterime sunulmuştur. 12 filmden oluşan seçki MUBI'nin 30 günlük deneme süresinden yararlanılarak ücretsiz izlenebilmiştir. İkinci olarak Cannes, Venedik ve Berlin film festivallerinden özenle seçilen 15 filmin Türkiye prömiyerleri, 15-29 Mayıs tarihleri arasında filmonline.iksv.org adresi üzerinden erişime açıldı. İkinci çevrimiçi gösterim seçkisi, 12-26 Haziran'da tarihlerinde gerçekleştirildi. İstanbul Film Festivali Direktörü Ayan, İstanbul Film Festivali ve online gösterimler hakkındaki düşüncelerini şu şekilde özetledi: "Festivalin fiziksel olarak gerçekleşmesi bizim için çok önemli. Festivaller öncesi ve sonrasıyla paylaşılarak büyüyor, film ekiplerinin ve izleyicilerinin katılımıyla zenginleşiyor. Dolayısıyla özellikle yarışmaların izleyiciyle ve ekiplerin katılımıyla yapılmaları çok önemli. Sonbahara doğru, 'yeni normal' günler geldiğinde İstanbul Film Festivali'nin nasıl fiziksel olarak gerçekleştirilebileceğini göreceğiz. Ama çevrimiçi gösterimlerin yalnızca İstanbul FF için değil dünyadaki birçok festival için hayatımızda daha büyük yer tutacağını söyleyebiliriz." (İstanbul, 2020)

Pandemi sürecinde yaşananları anlatan kısa film yarışmaları yaşananları kayıt altına alınmıştır. Bu bağlamda Akbank Kısa Film Festivali kapsamında Evde Kısa Film Yarışması, Beykoz Belediyesi "Korona Günlerinde Evde Hayat" kısa film yarışması düzenlemiştir.

Kriz ortamın da ulusal olduğu gibi uluslararası projeler de gerçekleştirildi. Bu projelerden biri de İngiliz yapımcılar Darwin Shaw ve Will Hawke, Covid-19'un dünyadaki etkilerini uluslararası bir proje ile kayıt altına almaya çalıştıkları Antiviral Film Projesi idi (Uluslararası, 2020). Proje kapsamında Türkiye'nin de dahil olduğu 24 ülkeden sinemacılar, 19 kısa film çekecek. Seçilen filmlerden "İzolasyon", "İlişki”" ve "Ortaya Çıkış" temalı 3 farklı uzun metraj film yapılacak. Projenin Türkiye temsilciliğini Shortbyshort.com’un kurucusu Bulut Reyhanoğlu yapıyor,

Pandemi sürecinde pek çok yönetmen ve yapım şirketi de filmlerini (Sofra Sırları-Ümit Ünal, Canavarlar Sofrasi-Ramin Martin, Körfez-Emre Konuk, Bir Tuğra Kaftancioğlu-Emre Akay ve Hasan Yalaz, Neredesin Firuze-Ezel Akay) ücretsiz olarak gösterime sundu. İstanbul Modern, Pera Film, Salt online gösterimler, söyleşiler gerçekleştirdi. Mithat Alam Film Merkezi Türkiye Sineması Görsel Hafiza Projesi'ni, İstanbul Experimental, Screening Room adını taşıyan online platformunda her gün arşivinden bir filmi erişime açtı. İstanbul Bienali her hafta film seçkisinden iki kısa filmi ücretsiz paylaştı. TRT EBA TV, cumartesi akşamları saat 21.00'de "Sinema Kuşağı" düzenledi. İzmir Kısa Film Festivali, karantina sürecinde de sinemaseverleri kısa filmlerle buluşturdu.

\section{Covid-19 Krizine Çözüm Önerileri}

Türk sinema endüstrisinin Covid-19 krizinden en az zarar ile kurtulabilmesi için sektör paydaşları farklı öneriler getirmektedir. Kırkalı, devletin hem sektör çalışanlarına, hem de film yapımlarına vereceği ekonomik desteğin çok kritik olduğunun altını çizmektedir:

"Ülkemizdeki tek devlet destekli film fonu olan Kültür Bakanlığı fonunun artması film üretiminin devam edebilmesinde büyük rol oynayacaktır. Aynı şekilde, sektörün önde gelen kurum 
ve kuruluşların da çalışanlarına sahip çıkması, imkânları el verdiğince maddi destekte bulunması çok kritik." (Çalışkan 3, 2020)

Devletin açıkladığı önlem ve destek paketlerinin sektöre bir oksijen sağlayacağını vurgulayan TESIYAP Başkanı Savcı, dünyanın ve Türkiye'nin geçtiği bu zorlu sınavdan kamu ve özel teşebbüsler bir araya gelerek geçebileceğini belirtmektedir (Box, 2020). Insignia Yapım'ın Kurucu-Yönetici Ortağı Acar'da devlet kurumlarının ve sektör paydaşlarının ortak akıl çerçevesinde bir araya gelmeleri gerektiğini belirtmektedir: "Türkiye Varlık Fonu, Kültür Bakanlığı, Maliye Bakanlığı, TRT ve sektör paydaşlarından oluşacak bir ortak akıl ile bir yol haritası belirlenmeli. Bu yol haritası için belli bir kaynak aktarılmalı ve bu kaynak da adil bir şekilde kullanılarak süreci minimum hasarla atlatabilmek sağlanmalı. Demek istediğim sarfi sürdürebilmeyi sağlamak ve sektörün bu büyük şoku atlatabilmesi için sektöre can suyu sağlamak.” (Yılmaz 4, 2020)

Sektörün bu süreçte hızlı bir şekilde bir araya gelmesi konusunda hem fikir olan yapımcılardan Okur, ancak Türk sinema endüstrisinin bu birlikten yoksun olduğunu söylüyor. Çözüm önerisi ise stratejik açıdan çok önemli olan sinema ve televizyon endüstrisine, kendi dinamiklerine uygun teşvik mekanizmalarının sağlanması. (Box, 2020) Erkılıç da Yamaç ile aynı görüşte sektöre özel bir teşvik politikasının uygulanması gerektiğini belirtmektedir: "Özellikle Avrupa ülkelerinde acil yardım fonları oluşturuluyor. Benzer bir çalışma bizim içinde geçerli ve acil. Sinema sektörünün proje temelli doğasına ve düzensiz iş döngüsüne, özel ihtiyaç ve uygulamalarına yönelik ekonomik teşvik paketi içeriğinin oluşturulması gerekiyor. Sektörü bir bütün olarak görmek ve sorunlara kapsayıcı çözümler getirmek gerekiyor. Sinema sektörü tüm bileşenleriyle daha çok iletişim içinde olup, birbirini anlayıp ortak çözümler üretmeli." (Yılmaz, 2020)

SİSAY'ın TC Kültür ve Turizm Bakanlığg'na ilettiği çözüm önerileri ise şu başlıklardan oluşmaktadır (Box Office, 2020):

1- Destek Paketinde açılanan konular (Muhtasar, KDV, SGK vergi ve primlerinin 6'şar ay ertelenmesi, salgının mücbir sebep sayılması ve kira ödemelerinin yapılmaması vb.)

2- Yıllardır sektörümüzün sırtında bir kambur olan, sinemaya hiçbir katkısı olmayan (\%10) Eğlence Vergisi'nin tamamen kaldırılması. Otellerde 1 Nisan'da yürürlüğe girecek olan (\%1) Konaklama Vergisi'nin bile uygulamaya giremeden ertelendiği belirttik. Kıyasla; \%1 Konaklama, \%10 Eğlence Vergisi!

3- Biletlerden/seyirciden \%8 KDV alınırken, film şirketlerine \%18 KDV ödenmesi. Aradaki fark orta ve küçük sinema işletmelerinin kârını yok etmektedir. Alış ve satışta \%8 KDV eşitlenmelidir.

4- Sinema ekipmanlarında ÖTV'nin kaldırılması.

5- Filmlerin sinemalarda vizyona girmesinden ücretli olarak 5 ay, ücretsiz olarak ise 6 ay sonra yayınlaması gereken mecraların, bu sürelerden önce yayın yapması durumunda yaptırım/ceza uygulanmas1.

6- Dünyadaki en kısa sürelerden biri olan bu uygulamanın 11/12 aya çıkarılması.

Film Yapımcıları Meslek Birliği Başkan Yardımcısı Nazif Tunç’ta SİSAY ile örtüşen çözüm önerilerini şöyledir (Yılmaz 2, 2020):

1. Sinema sektörünün tüm birleşenlerinin, yapım şirketlerinin, salon işletmelerinin, dağıtım şirketlerinin vergi ödemelerinin bir yıl ertelenmesi, birikmiş pirim ve vergi borçlarının faizsiz olarak uzun vade ile yapılandırılmalı.

2. Yapım şirketlerine, salon işletmelerine faizsiz ve uzun vadeli krediler verilmeli.

3. Sinema salonlarına hayatın olağan akışı başlayana kadar kira yardımı yapılmalı. 
4. Yeni sinema yönetmeliğinde yer alan "filmlerin sinema vizyon tarihinden en az 5 ay sonra internet gösterimlerine izin verilmesi" şeklindeki düzenleme kaldırılmalı, süre aralıkları sözleşmelerle belirlenmelidir.

5. Sinemamız için filmler, diziler üretmiş eser sahiplerinin beklediği telif yasası, bu sıkıntılı günlerin getirdiği dayanışmaya yaslanarak bir an önce çıkarılabilir. Böylece filmlerden, dizilerden, çevrimiçi mecralardan az da olsa toplanacak telifler, eser sahibi sanatçllara bekledikleri müjde olabilir.

Endüstride yıllardır tartışılan eğlence vergisinin kaldırılması gerektiğini söyleyen Fırat, yeni sinema yasasıyla birlikte kaldırılan bilet kampanyalarının normalleşme sürecinde ekonomik zorlukları aşmak adına kullanılabilecek enstrümanlardan biri olduğunu söylemektedir (Box, 2020).

Kılıç bu öneriler bütününde kısa vadede Covid-19 krizinin ekonomik ve sosyal tahribatına, uzun vadede ise sektörün yapısal sorunlarına odaklanılması gerektiğini ifade etmektedir (Yılmaz, 2020). Akbulut'ta endüstri için kısa ve uzun vadeli iki çözüm planının yürütülmesi gerektiğini söylemektedir. Kısa vadede yerli film sektörünü desteklemek için, özellikle yeni filmlerin online platform gösterimlerini belirli bir süre ertelemek, sinema yasasını, günün koşullarına uygun biçimde ve kültürel çeşitliliğe, çok sesliliğe olanak verecek biçimde sektörün bileşenleriyle birlikte yeniden düzenlemek; seyirciler için beğeni çeşitliliği sağlayacak bir düzenleme yapılması gibi acil konular yer alıyor (Zeyrek, 2020). Uzun vadede ise geniş bir kültür politikası belirlenmeli ve bu politikaya yön verecek politik aktörlerin, ilgili sektörün (sinema meslek kuruluşları, sendikalar, üniversiteler gibi) temsilcilerinden oluşan bir kurul kurularak özerk bir yapının oluşturulmasını öneriyor.

Sürecin devam etme ihtimali ise film çekim süreçlerini oldukça zora sokacaktı. Çünkü pandemiden dolayı eski şartlarda rahat çekim yapmak mümkün değildi. Yeni kurallar ve tedbirlerle hızlı, başarılı ve sinematografik çekim yapmak zor görünüyordu.

\section{Sonuç}

Bütün dünyayı etkileyen Covid-19 pandemisi pek çok endüstrinin işleyişini durdurdu. Covid-19'dan en çok etkilenen endüstrilerden biri de sinema endüstrisi oldu. Mısır savaşları, sinema kanunun değişmesi, dijital platform tartışmaları ile birlikte sorunlu bir 2019 yılı geçiren Türk Sineması, Covid-19 krizi ile derinden sarsıldı. Endüstrinin tüm aşamalarının durması ekonomik anlamda büyük zarara yol açtı, binlerce kişi işsiz kaldı, sinemalar kapandı, festivaller, yarışmalar, etkinlikler iptal edildi, ertelendi.

Fikir aşaması için genişleyen zaman dilimi ile birlikte sektör, birikmiş projelerini değerlendirme, mevcut projelerini daha da iyileştirme ve geliştirme, yeni projeler üretme firsatı buldu. Bir anlamda bu aşama bir nefes alma dönemini yaşadı. İsabetli oyuncu seçimleri, yeni oyuncuların keşfi, oyuncu ve okuma provaları, deneme çekimlerini (audition) izleme özet olarak cast tasarımı için çok daha sistemli çalışma ortamı oluştu. Teknik cihazların temizliği ve kontrolü rahat ve özenli bir şekilde yapıldı.

Pandemi, bu aşamada olumlu tarafından bakıldığında, endüstri paydaşlarının hedef kitleyi, kendilerini ve endüstrinin tamamını gözden geçirip analiz etmeleri, çözüm yolları üretmeleri için de önemli bir firsattır. Endüstrinin tüm aşamaları düşünülerek daha sağlam adımlar atmak için bu süreç iyi değerlendirilmelidir.

En sorunlu aşamalardan biri olan üretim aşamasının gecikmesi sektörde zincirleme bir aksamaya neden olacaktır. Gösterim için yeterli filmin olmaması Türk sinema endüstrisini zayıflatacaktır. En yoğun olunan dönemde maddi olarak büyük kayba uğrayan yapım şirketleri yeni projelerin birçoğunu askıya almışlardır. Gösterimi yarıda kalan ve ertelenen fillmlerden dolayı yeni sezonda yaşanacak sıkışıklık uygun vizyon tarih almayı engelleyeceğinden bazı filmlerin çekimleri de önümüzdeki yıllara ertelenmiştir. Pandemi kuralları çerçevesinde çekim yapmanın zorlaşması, maliyeti arttırması yapım şirketlerini sete çıkmaktan vazgeçirmektedir. 
Endüstri de artan maliyetler ile birlikte yapım şirketleri riskli projeler yerine daha uygun bütçeli ve hızlı bir şekilde çekilip vizyona hazır hale getirilebilecek daha sade film projelerine yönelecektir. Çekim sürelerinin kısalması için dekor, mekân, kostüm, 1şık gibi hazırlık gerektiren süreçlerden taviz verilmesi gerekecektir. Bu da dramatik yapısı, görsel gücü, sinematografik anlatımı zayıf filmlerin çekilmesine zemin hazırlayacaktır. Başka bir açıdan film şirketlerinin çok film yerine özenle çekilecek daha az filme yatırım yaparak endüstriye kaliteli ürünler sunma ihtimalleri de vardır. Bununla birlikte bağımsız sinemacıların pek çok yönden alışkın olduğu bu sıkıntılı süreç minimal ve başarılı film çekmek için uygun bir ortam oluşturmaktadır. Farklı, yenilikçi ve özgün projelerin yeni bir dil ile ortaya konabilmesi mümkündür.

Sinema endüstrisinin zarar gördüğü en büyük aşama dağıtım ve gösterim aşaması olmuştur. Sinemaların kapanması ile birlikte bu aşamada büyük oranda durmuştur. Endüstriye nakit akış1 sağlayan bu büyük gelir kaynağı sektörün en yoğun olduğu dönemde kapanmak zorunda kalmıştır. Bu süreçte dünya sinema endüstrisi kadar olmasa da çok daha az bir etkinlikte son yıllarda popüler hale gelen dijital platformlar, yeni bir gösterim mecrası olarak devreye girmiştir. Dijital platformlar Covid-19 pandemi sürecinde ön plana çıkmıştır. Sosyal hayattan izole bir şekilde evde kalma zorunluluğu bu süreci katkı sağlamıştır. Bununla birlikte çeşitli ve zengin içerikleri, mekân ve zamandan bağımsız bir şekilde ve özellikle güvenli bir ortamda izleme olanağa sunması dijital platformları tercih edilebilir kılmıştır.

Türk sinema endüstrisi için çok yoğun bir gösterim süreci olmasa da online siteler ile birlikte dijital platformlar belirsizliğin sürdügü, krizin etkilerinin devam edeceğinin işaretlerini verdiği bu dönemde yapım şirketleri ve dağıtımcılar için stratejik bir gösterim mecrasıdır. Başka Sinema ve Blu TV, İKSV ve MUBİ işbirliği, İstanbul Film Festivali'nin online gösterimleri bu anlamda örnek uygulamalar olmuşlardır. Dijital platformlar ve benzer online çözümler, kriz ortamlarından maddi katkı ile birlikte seyirci ile buluşma noktasında işlevsel bir yapıda olduklarını göstermişlerdir.

Covid-19 krizi dijitalleşme sürecinde katalizör görevi görerek dijitalleşmenin sinema endüstrisi değerler zinciri içerisinde yer alması gerektiğini gösterdi. Endüstri için yeni iş modelleri tanımlarının yapılmasının gerektiği ortaya çıktı. Dijital platformlar ile birlikte sosyal medya ağları, web siteleri, online platformlar endüstrinin hedef kitle ile buluşmasında farklı ve alternatif yollar olarak dikkat çekti.

Sürecin belirsizliği ve insanların salgın yüzünden sinemaya olan tedirginliği, endüstri üzerinde negatif bir algı oluşturmuş durumdadır. Özellikle "yeni normal" adı verilen süreçte seyircilerin sinemaya çok daha sınırlı sayıda gidecektir. Sinema salonları, yeni kurallar ve tedbirlere göre düzenlenerek kontrollü bir şekilde yeni normalleşme sürecinde sinemaseverlerine kapılarını açabilir. Sinemalara temkinli yaklaşan sinema seyircisi zaman içerisinde disiplinli bir şekilde devam ettirilen kurallı gösterimler, indirimli biletler ve ikna edici pazarlama yöntemleri ile sinemaya gelmeye başlayacaktır.

Yıllık film üretimi az olan Türk Sineması için Covid-19 krizi sonrası yeni çekim şartlarında film üretimi daha da azalacaktır. Bu da vizyona girecek film sayısında bir düşüşe sebep olacaktır. Sinema salonları açığı kapatmak için vizyondaki filmlerin süresini uzatabileceği gibi yabancı filmler ile açığı doldurmaya çalışacak ya da salon ve seans sayılarını azaltacaktır.

Kapalı sinema salonları yerine mevsimin uygun olduğu şartlarda ve şehrin el verdiği imkanlar dahilinde arabalı sinemalar, açık hava sinemaları bir çözüm yolu olarak ortaya konabilir. $\mathrm{Bu}$ sayede sinema seyir kültürü canlı tutulmuş olacaktır.

Covid-19'un krizinden büyük zarar gören bir gösterim mecrası da festivaller olmuştur. Türk sinema endüstrisinin bir araya gelmesini sağlayan, yeni film ve yönetmenleri vitrine taşıan festivaller, bu dönemde etkisini kaybetmiştir. Ancak online projeler ile dijital dünyaya taşınarak farklı bir deneyim yaşamış ve yaşatmışlardır. Bu da etkinliklerin tüm olumsuzluklara rağmen devam 
etmesi anlamında olumlu bir gelişmedir. Özellikle önemli tematik festivallerin online gösterimler ve etkinlikler yapmaları sinemaseverler ile bağlarını sıkı tutmaları anlamında çok olumlu olmuştur. Film yarışmalarının birçoğu iptal edilmiş, endüstri bu yönü ile çok zayıf bir yapıda olduğunu göstermiştir. Son yıllarda şehir, kurum tanıtım aracı olarak kullanılsa da film yarışmaları, yeni sinemacıların yetişmesinde ve sektör ile buluşmasında önemli bir işleve sahiptir.

Sinema seyircileri salonlara gidemeseler de farklı yönlerde sinema anlamında zengin bir süreç yaşadılar. Özellikle yapım şirketlerinin, yönetmenlerin, kültür-sanat kuruluşlarının ve çeșitli vakıfların belgesel, kurmaca, kısa, deneysel filmlerini video çalışmalarını ücretsiz olarak sunmaları, sinemaseverlerin farklı yapımlar ile tanışmalarına yardımcı oldu. YouTube, Instagram, Zoom vb. sosyal medya ağları ve uygulamalar ile sinemanın farklı yönlerini elen alan pek çok söyleşinin, sohbetin, röportajın, programın, atölyenin gerçekleştirilmesi, sinema birikimin paylaşılması anlamında çok etkili oldu. Sinema profesyonelleri sinemaseverlere tecrübelerini, bilgi birikimlerini aktardılar. Sinema endüstrisinin kamera önü ve arkasının emekçileri, akademisyenler, sinema yazarları sosyal medya hesaplarından yaptıkları canlı yayın ve programlarla, tecrübe ve bilgi paylaşımı gerçekleştirdiler. Oyunculuk, yönetmenlik ve senaryo gibi sinema eğitimleri online verilmeye başlandı. Aynı şekilde film festivallerinin özenle hazırladıkları seçkileri online olarak göstermeleri, etkinlikler düzenlemeleri, sinemaseverler ve özellikle genç sinemacılar için verimli bir eğitim ortamı hazırladı.

Bu süreçte eski, yeni birçok film ile tanışıldı ve sinema üzerine düşünmeye, yazmaya, proje üretmeye bolca vakit ayrıldı. Farklı ülke sinemalarını tanıma firsatı yakalayan sinemaseverler nitelikli bir izleme süreci geçirdiler. Türk sinema endüstrisinde üç aylık bir online iletişim süreci gerçekleştirildi. İlk defa bu kadar yoğun ve kalabalık gerçekleştirilen iletişim sayesinde artan etkileşim ilerleyen süreçte yeni inovatif fikirlerin doğmasına sebep olacaktır.

Türk sinema endüstrisi farklı unsurları devreye girerek sinemaya olan ilgili sıcak tutmaya çalıştı. Bir taraftan evde sıkılan insanlara alternatif gösterim ve etkinlik firsatları sunulurken diğer taraftan sinema kültürüne önemli katkılar sağlandı.

Türk sinema endüstrisi tüm değerler zinciri ile birlikte derinden sarsıldığı, doğrudan ve dolaylı olarak birçok sektörü etkilediği bu kriz ortamından çok kısa bir sürede kurtulamayacaktır. Pandemi sürecinin belirsizliği ve şu ana kadar ki açtığı zarar ile birlikte oluşturduğu olumsuz alg1 uzun bir süre Türk Sineması'nda hissedilecektir. Türk Sineması üretim tarzında değişiklilere gitmek zorunda kalacaktır. Maddi zarar ile birlikte sektörün yıpranmış yapısı Türk sinema endüstrisini küçülmeye götürecektir.

Netflix ve Başka Sinema'nın endüstrinin farklı unsurlarına oluşturduğu destek dışında sektöre özel bir teşvik, destek ya da fon oluşturulmamıştır. Devlet yardımı genel ekonomik destekler kapmasında sınırlı kalmıştır. Türk sinema endüstrisinin kırılgan bir yapıda olduğu gerçeğinin gün yüzüne çıtığı Covid-19 krizinin aşılması ve endüstrinin yapısal sorunlarının çözülebilmesi için devlet ve özel sektörün tüm paydaşların bir araya gelerek ortak akıl çerçevesinde çözüm üretmeleri ve bir yol haritası çıkarmaları gerekmektedir. Endüstrinin sağlıklı bir şekilde normal işleyişine dönebilmesi için birlik ve beraberlik içinde çalışmaların yürütülmesi şarttır.

\section{Kaynakça}

Aydemir, Ş. (2020, 7 Haziran). Ne olacak bu sinemanın hali? / 2: Daralma yüzde 50'leri aşabilir, https://www.evrensel.net/yazi/86494/ne-olacak-bu-sinemanin-hali-2-daralma-yuzde-50leriasabilir. 
Aydemir 2, Ş. (2020, 7 Haziran). Ne olacak bu sinemanın hali? / 1: Setlere dönüş, öncelik dizilerde, https://www.evrensel.net/yazi/86442/ne-olacak-bu-sinemanin-hali-1-setlere-donus-oncelikdizilerde

Bayrak, İ. (2020, 29 Nisan). mail Sinemay1 neler bekliyor?, https://www.hurriyet.com.tr/kelebek/magazin/sinemayi-neler-bekliyor-41504781, ET: 29.04.2020

Box Office Türkiye: "İnsanlar sinemaya özlem duyuyor", https://boxofficeturkiye.com/haber/boxoffice-turkiye-insanlar-sinemaya-ozlem-duyuyor--2593, ET: 17.05.2020

Box Office Türkiye: "Sinemada normalleşme süreci 6 aydan uzun sürebilir", 13.04.2020, https://boxofficeturkiye.com/haber/box-office-turkiye-sinemada-normallesme-sureci-6aydan-uzun-surebilir--2568, 16.06.2020

Bulovalı, A. H. (2020, 6 Haziran). Yönetmen Atalay Taşdiken: Sinemanın sorunlarının katlanacağı bir sürece gidiyoruz, https://www.aa.com.tr/tr/kultur-sanat/yonetmen-atalay-tasdikensinemanin-sorunlarinin-katlanacagi-bir-surece-gidiyoruz-/1866383, ET: 06.06.2020

Büyüköztürk, Ş., Çakmak, E. K., Akgün, Ö. E., Karadeniz, Ş. ve Demirel, F. (2008). Bilimsel araştırma yöntemleri (2. Baskı). Ankara: Pegem Akademi

Çalışkan, M. (2020, 14 Haziran) Ferhat Aslan, karantinadan sonra sinemada olacakları anlattı, ET: 16.05.2020, https://www.haberturk.com/ferhat-aslan-karantinanin-sinemaya-etkilerinianlatti-2677238

Çalışkan 2, M. (2020, 5 Haziran) Sinemada normalleşme ne zaman?, https://www.haberturk.com/sinemada-normallesme-ne-zaman-2701886

Çalışkan 3, I. (2020, 12 Haziran) Yeni normal bedava uygulanmaz, https://www.birgun.net/haber/yeni-normal-bedava-uygulanmaz-30413

Çalışkan 4, M. (2020, 27 Mayıs). Sinemalarda bilet ücretleri azalacak mı?, https://www.haberturk.com/sinemalarda-bilet-ucretleri-azalacak-mi-2690775

Disney+ global olarak 50 milyon aboneye ulaştı, ET: 10.06.2020, https://boxofficeturkiye.com/haber/disney-global-olarak-50-milyon-aboneye-ulasti--2564.

Evren, B. (1996) Mahallecek Gidilen Sinemalar, İstanbul Dergisi, sayı 18, Tarih Vakfi Yayınları

Hatunoğlu, G. (2020, 5 Haziran). "Yeni normal" ile "eski normal" arasında ne olacak sinemanın hali, https://www.evrensel.net/haber/406341/yeni-normal-ile-eski-normal-arasinda-ne-olacaksinemanin-hali, ET: 05.06.2020.

İleri, E. (2020, 27 Nisan). Salgın Günlerinde Sinema Dünyas1 Ne İstiyor?, https://www.gazeteduvar.com.tr/sinema/2020/04/25/sinema-dunyasinda-gundem-salgin-neistiyoruz/

İleri 2, E. (2020, 18 Haziran). sin Belki şehre bir film gelir: Açıkhava sinemaları geri döner mi?, https://www.gazeteduvar.com.tr/sinema/2020/05/17/belki-sehre-bir-film-gelir-acikhavasinemalari-geri-doner-mi/

Kaplinsky, R. Morris, M. (2016, 2 Temmuz). A Handbook for Value Chain Research IDRC, http://www.srp-guinee.org/download/valuechain-handbook.pdf.

Karayel, F. (2020, 5 Mayıs). 'Sinema endüstrisini ayağa kaldırmak için bir projemiz var', 03 Mayıs 2020, Pazar, https://www.sabah.com.tr/yazarlar/gunaydin/fundakarayel/2020/05/03/sinema-endustrisini-ayaga-kaldirmak-icin 
Kulaklı, G. (2020, 16 Nisan), Koronavirüs Nedeniyle Ertelenen Marvel Filmlerinin Yeni Vizyon Tarihleri, https://www.webtekno.com/koronavirus-nedeniyle-ertelenen-marvel-filmlerih89420.html.

Kurt, A. A. (2013). Bilimsel Araştırma Yöntemleri, Anadolu Üniversitesi Yayınları

Küstür, S. (2020, 9 Nisan). Disney Plus abone sayısını hızla artırmaya devam ediyor, https://www.teknoblog.com/disney-plus-abone-sayisini-hizla-artirmaya-devam-ediyor/

Özdemir, Ö. (2020, 16 Mayıs). e Film ve dizi izleme tavsiyeleri: Sinema yazarları karantinada ne izliyor?, https://www.bbc.com/turkce/haberler-dunya-52656283

Özgül, T. (2020, 5 Haziran). Sizin İçin Etraflıca Anlattık: Salgın Sinema ve Dizi Dünyasını Nasıl Etkiledi, İzleyicileri Neler Bekliyor?, https://www.webtekno.com/covid-19-salgini-vesinema-ve-dizi-dunyasi-h93644.html

Sinema izleyicisi 2019'da azald, https://www.sozcu.com.tr/hayatim/kultur-sanat-haberleri/sinemaizleyicisi-2019da-azaldi/, ET: 16.05.2020

Sinema Salonu Yatırımcıları Derneği başkanı İrfan Demirkol, sinemaların açılış tarihiyle ilgili açıklamalarda bulundu, 27.05.2020, https://boxofficeturkiye.com/haber/sinema-salonuyatirimcilari-dernegi-baskani-irfan-demirkol-sinemalarin-acilis-tarihiyle-ilgiliaciklamalarda-bulundu--2645, ET: 16.05 .2020

Uluç, H. (2020, 13 Mayıs). Ya bizim sinemalar ne olacak?, (15 Mayıs 2020), https://www.sabah.com.tr/yazarlar/uluc/2020/05/15/ya-bizim-sinemalar-ne-olacak, ET: 15.05.2020

Uluç 2, Hıncal (2020, 13 Mayıs). Sinemaların sonu mu geliyor!.., https://www.sabah.com.tr/yazarlar/uluc/2020/05/13/sinemalarin-sonu-mu-geliyor, ET: 14.05.2020.

Zeybek, B. (2020, 19 Haziran). Prof. Dr. Hasan Akbulut: “Onlıne Platformlar Düşmanlaştırılmadan Seyir Pratiği Çoğullaştırılmalı", 12 Nisan 2020, http://sineblog.org/ozel-soylesi-prof-drhasan-akbulut-online-platformlari-dusmanlastirmadan-seyir-pratigi-cogullastirilmali/

Zeybek 2, B. (2020, 19 Haziran). Ulaş Yiğit Ülker: "Netflix Çıktı Diye Sinemacılık Veya Salonculuk Bitmedi”, 19.04.2020, http://sineblog.org/ozel-soylesi-ulas-yigit-ulker-netflix-cikti-diyesinemacilik-veya-salonculuk-bitmedi/.

Tezel, M. (2020, 21 Haziran). Sinemada kayı \% 59, (17 Nisan 2020), https://www.sabah.com.tr/yazarlar/gunaydin/sb-mevlut_tezel/2020/04/17/sinemada-kayip59

Türk sinema sektörü çekimlere başliyor, https://www.iha.com.tr/haber-turk-sinema-sektorucekimlere-basliyor-847128/, ET: 27.05.2020

Sinema-TV Sendikasi: 'Yeniden başlayan setler durdurulsun', http://www.cumhuriyet.com.tr/haber/sinema-tv-sendikasi-yeniden-baslayan-setlerdurdurulsun-1733269, ET: 18.04.2020.

Sungur, E. (2020, 25 Nisan). Mandıra filozofu sinemayı kurtaracak, https://www.milliyet.com.tr/ekonomi/mandira-filozofu-sinemayi-kurtaracak-6198908, ET: 25.04.2020.

Vergi Konseyi, Film Sektörümüzün Kurumsallaşması ve Dışa Açılması, Ağustos-2007.

Worhıngton, C. (2011). Yapım, Literatür Yayınları, İstanbul 
Yılmaz, Z. (2020, 17 Haziran). Doç. Dr. Hakan Erkılıç: "Dijital Platformların Yükselişini Dillendirmek Sinemaya İhanet Değil”, http://sineblog.org/ozel-soylesi-doc-dr-hakanerkilic-dijital-platformlarin-yukselisini-dillendirmek-sinemaya-ihanet-degil/

Yılmaz 2, Z. (2020, 17 Haziran). Nazif Tunç: "Sinema Sanatının Ululuğu Seyircinin O Karanlık Salondaki Teslimiyetiyledir" http://sineblog.org/ozel-soylesi-nazif-tunc-sinema-sanatininululugu-seyircinin-o-karanlik-salondaki-teslimiyetiyledir/

Yılmaz 3, Z. (2020, 17 Haziran). Şenay Aydemir: "Sinema Salonlarına İlgi Eski Haline Dönecek", http://sineblog.org/ozel-soylesi-senay-aydemir-sinema-salonlarina-ilgi-eski-halinedonecek/, 18 Nisan 2020|, ET: 19.06.2020.

Yılmaz 4, Z. Z. (2020, 17 Haziran). Dorukhan Acar: "Sektörün Şoku Atlatabilmesi İçin Sosyal Kapitalizm Şart", 20.04.2020, http://sineblog.org/ozel-soylesi-dorukhan-acar-sektorunsoku-atlatabilmesi-icin-sosyal-kapitalizm-sart/, 17.06.2020

Yıldırım, A. ve Şimşek, H. (2005). Sosyal bilimlerde nitel araştırma yöntemleri. Ankara: Seçkin Yayınc1lı. 